Portland State University

PDXScholar

$11-21-1985$

\title{
Concrete Poetry: The Influence of Design and Marketing on Aesthetics
}

Tineke Bierma

Portland State University

Follow this and additional works at: https://pdxscholar.library.pdx.edu/open_access_etds

Part of the German Literature Commons, and the Poetry Commons Let us know how access to this document benefits you.

\section{Recommended Citation}

Bierma, Tineke, "Concrete Poetry: The Influence of Design and Marketing on Aesthetics" (1985).

Dissertations and Theses. Paper 3438.

https://doi.org/10.15760/etd.5321

This Thesis is brought to you for free and open access. It has been accepted for inclusion in Dissertations and Theses by an authorized administrator of PDXScholar. Please contact us if we can make this document more accessible: pdxscholar@pdx.edu. 
AN ABSTRACT OF THE THESIS OF Tineke Bierma for the Master of Arts in German presented November 21, 1985.

Title: Concrete Poetry: The Influence of Design and Marketing on Aesthetics.

APPROYED BY MEMBERS OF THE THESIS COMMITTEE:

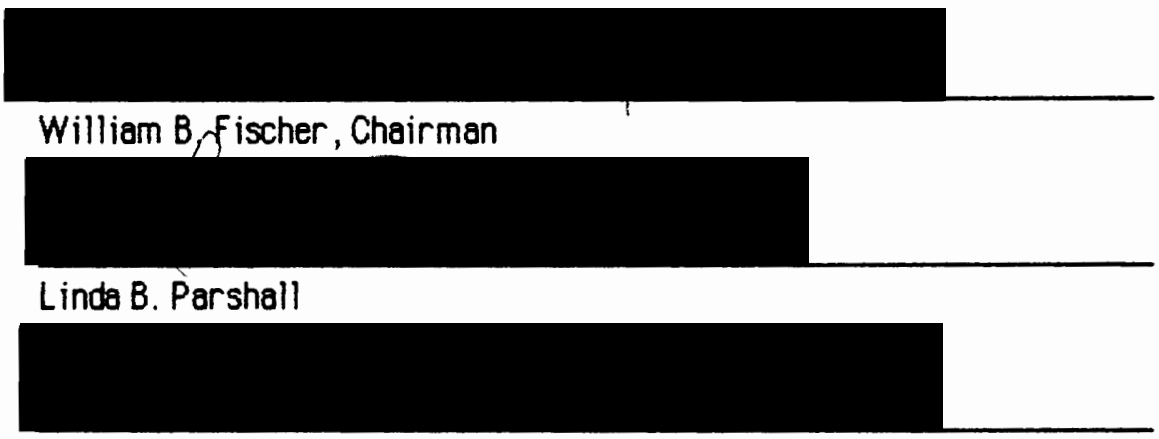

Thomas Buell

This thesis explores the past and present of concrete poetry with the purpose of finding out whether concrete poetry is still being produced in its or iginal form, or whether it has changed.

Concrete poets were not the first ones to create picture poems and similar texts. In chapter I an overview of earlier picture poetry is given. It and other precursors of concrete poetry are discussed and their possible contributions evaluated.

Chapters II and III deal with the definition of concrete poetry of the mid-fifties and sixties ( pure, classic c.p.). They focus primarily on German, Austrian and Swiss poets. Manifestoes are examined and individual poems are discussed in detail. The many different kinds of concrete poetry that developed after 1970 are mentioned without any further discussion.

One of the outstanding features of concrete poetry is its innovative use of typography. In chapter IV the development of the printing process is explained. Along with the technological 
advancements, (which not only increased output but also created new possibilities for page design) examples are given which make use of these advancements. Chapter $V$ gives a short history of typography, at one time part of the printing process.

Chapter $\mathrm{Vl}$ of the thesis deals with the convergence of typographic design and concrete poetry in advertising. Examples of advertisements are given and their strengths and weaknesses as concrete poems are pointed out.

The concluding chapter argues that the creation of pure (classic) concrete poetry had ended by the late sixties, a fact confirmed by letters the writer received from concrete poets in Germany and Austria (Mon, Döhl, Gappmayr). The chapter shows furthermore that the tradition of the classic concrete poetry has been carried over into some of today's advertisements.

Thus up to 1970 the term "concrete poetry" referred to classic concrete poetry. After 1970 "concrete poetry" became a collective name for many different kinds of experimental poetry. In East Germany concrete poetry remained a lyrical poetry that had little in common with the innovative poetry of the West. In West Germany the "Hörspiel" carries on the ideas of concrete poetry in the form of acoustic poetry. In other countries (Italy, the Netherlands) it has moved from aesthetic communication to a poetry with a message.

Yet concrete poetry remains an experimental poetry, typified by constant changes, which keeps challenging the reader, peruser, listener to participate and to enjoy it. 
CONCRETE POETRY:

THE INFLUENCE OF DESIGN AND MARKETING ON AESTHETICS

by

TINEKE BIERMA

A thesis submitted in partial fulfillment of the

requirements for the degree of

MASTER OF ARTS

in

GERMAN

Portland State University

1985 
TO TIT: OFFICS OF GRADUATE STUNTFS AND REGEARCH:

Tre members of the Committee anprove the thesis of Tinele Bjerma presented Novemher 21, 1935.

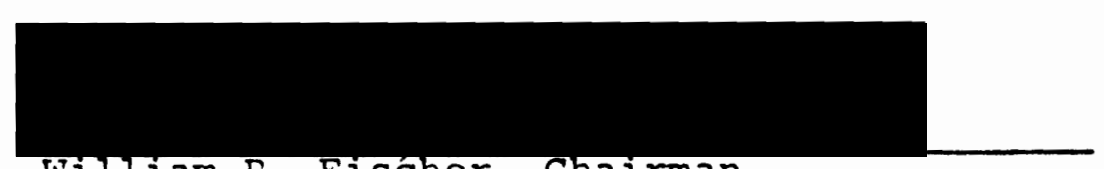

"illian,. Fischer, Chairman

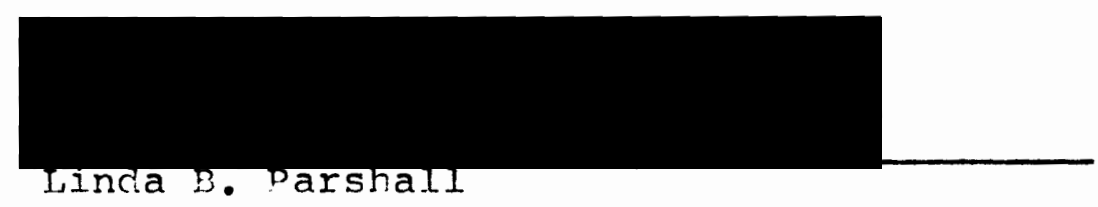

Thomas Puell

APPPNUT:

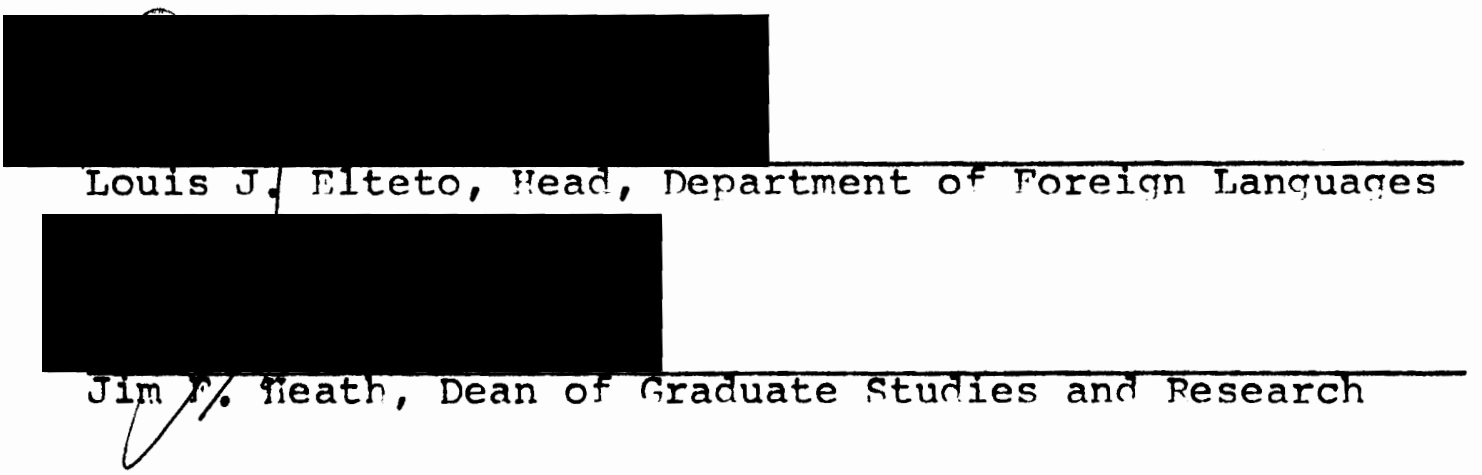




\section{TABLE OF CONTENTS}

I HISTORICAL BACKGROUND $\ldots \ldots \ldots \ldots \ldots \ldots \ldots \ldots \ldots \ldots$ I

NOTES $\ldots \ldots \ldots \ldots \ldots \ldots \ldots \ldots \ldots \ldots \ldots \ldots \ldots \ldots \ldots \ldots$

II CONCRETE POETRY TILI, 1970: THEORIFS ......... 9

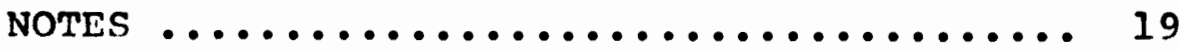

II I DEMONSTRATIVE ANALYSES $\ldots \ldots \ldots \ldots \ldots \ldots \ldots \ldots \ldots 22$

NOTES.......................... 40

IV CONCRETE POETRY AND TECHNOLOGY ............ 45

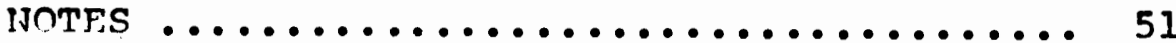

V TYPOGRAPHY AND CONCRETE POETRY $\ldots \ldots \ldots \ldots \ldots \ldots .53$

NOTES $\ldots \ldots \ldots \ldots \ldots \ldots \ldots \ldots \ldots \ldots \ldots \ldots \ldots \ldots$

VI CONCRETE POETRY AND ADVFRTISING .......... 60

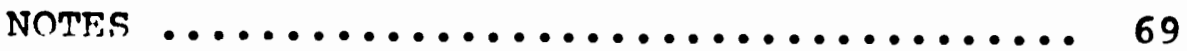

VII SUMPIARY $\ldots \ldots \ldots \ldots \ldots \ldots \ldots \ldots \ldots \ldots \ldots \ldots \ldots \ldots . \ldots . \ldots 1$

NOTES $\ldots \ldots \ldots \ldots \ldots \ldots \ldots \ldots \ldots \ldots \ldots \ldots \ldots \ldots \ldots$

BIBLIOGRAPHY $\ldots \ldots \ldots \ldots \ldots \ldots \ldots \ldots \ldots \ldots \ldots \ldots \ldots \ldots \ldots \ldots \ldots$ 
CHAPTER I

\section{HISTORICAL BACKBROUND}

After reading about concrete poetry, which so strongly emphasizes innovation, one gains the impression that it is a completely new phenomenon. Dick Higgins writes: "The concrete poets have tended to take the usual neoteric position and to dismiss the obvious lineage of their work through such pieces as Lewis Carroll's "The Tale of a Mouse" (for English), Panard's 'Glass' and 'Bottle" for French, or the Apollinaire 'Calligrammes'." concrete poetry from as far back as the ancient Oreeks: "ist man aber erst einmal auf der Suche nach Vorläufern oder Vorbildern, ist der Sprung vom Dadaismus zu Apollinaire, Mallarmé oder auch einigen Barockpoeten nicht weit, und so dringt man immer weiter vor und findet sich überraschenderweise bei den Griechen...."2 Some examples of the earlier picture poems of antiquity and the 16th and 17 th century along with a discussion of the more direct precursors, among them Mallarmé, the Futurists, Arno Holz, Guillaume Apollinaire, the Dadaists and Theo van Doesburg, will help gain a better understanding of their importance.

Around 300 B.C. Simmias of Rhodes wrote a Greek love poem in the shape of wings. $3 \mathrm{He}$ also created technopaignia in the shape of an ax and an egg. 4 "Technopaignia" is the modern name for the visual texts (which form the shape of an object) of antiquity. Other texts from about 300 B.C. are the "syrinx" or "shepherd's pipe" by Theocritus and the "altar" by Dosiades.

It is not until 400 A.D. that technopaignia appear again. Porphyrius created poems in the shape of an altar and a syrinx. ${ }^{5}$ Two centur ies later Yenantius Fortanus ( $530-600$ A.D.) formed the next link in the chain of technopaignia. He wrote four poems which definitely show Porphyrius' influence. The most complicated one is a cross in grid format. St. Boniface composed 
a text in which he outlined a cross by drawing lines between the letters. ${ }^{6}$ During the Carolingian era there were too many creators of technopaignia to be mentioned here. ${ }^{7}$ Eugenius Vulgarius is the most important such poet of his time. About 950 A.D.he wrote grid poems and a poem in the shape of an organ. Vulgarius' organ shows a strong resemblance with Porphyrius' "Syr inx."

In the 16th century picture poems appear more frequently. Kessler mentions at least ten poets who made poems in the shape of an ax, a pillar or a cross. He names Julius Cäsar Scaliger (1484-1558) as the poet most important to the continuation of visual texts. 8 The poets of the 17 th century ventured beyond the examplary ax and altar. They made poems which resembled a heart, a flower wreath, a shepherd's cottage, and other shapes. ${ }^{9}$ Around 1650 Johann Klaj wrote a German poem in the shape of a pillar. 10 The picture poem became an "'occasion poem" ("Gelegenheitsgedicht"). The shape of the poem reflected the occasion it was used for.

The years between 1640-1680 were the most important for picture poems. After that they virtually disappeared. "I The poem about Berlin, written by Johann Leonard Frisch in 1700 has the shape of a bear, emblem of Berlin. 12 The Frenchman Panard created poems in the shape of a bottle and a glass. 13 Thus far the outstanding feature of these picture poems was their shape rather than their content.

In 1865 Lewis Carroll wrote Alice's Adventures in Wonderland. In the story the tale of the mouse is printed in the shape of a tail. ${ }^{14}$ Carroll's "The Tale of a Mouse" is the most significant picture poem of the 19th century, because here emerges the double function and pun; "tale" the story being told and "tail" at the same time. 15

Concrete poetry has not only a visual tradition rooted in the technopaignia; it also has a literary tradion in the form of the Proteus poems. ${ }^{16}$ Scaliger was the first in the 16 th century to create a Proteus poem. The name of the poem was " "Perfide sperasti diuos to fallere Proteu," which tranlated into German means, "Frevelhaft hast du, Proteus, die Oötter zu tauschen gehofft." 17 The poem is called a "Proteus poem" because the six words of the title can be interchanged many times. For Scaliger , according to Christian Wagenknecht, a poem can only be a "Proteus" poem if its meaning is close to those expressed by the many interchanges of the words. 
In the present case the name is based on an analogy; just as the changes of the sea god cannot hide his identity, so does the poem remain recognizable in all its changes. 18 Wagenknecht calls Scaliger's Proteus poem "ein poetischer Glücksfall, ein sinnreiches Werk, ein Muster- und Meisterstück der späthumanistischen Kunstpoesie." Scaliger's contemporaries followed his example, using many different subjects for their poems. ${ }^{19}$ At the end of the 17th century Johann Casper Schade wrote a poem based on the psalm verse, "Oott, du bist mein Oott." The poem explores a wealth of thoughts by changing the position of the words twenty five times. 20

There exist no Proteus poems from the 18th and 19th centuries. Proteus poems appear again in the experimental poetry of the 1960s and 1970s under the name of "Permutations." And even though the permutations sometimes do not even contain sentences, according to Wagenknecht, there are many features which are reminiscent of "die Formspiele der älteren Zeit." 21 The Proteus poem is from a time period when "artistic refinement of poetic grammar" ("künstliche Verfeiner ung der poetischen (rammatik") was very important. The aim of the concrete poets was the opposite. They wanted to simplify the language and reduce it to basic components. 22

The French poet Stéphane Mallarmé is the most remarkable author, next to Oornringer, to influence the development of concrete poetry, 23 according to Kessler. The "Pilot Plan for Concrete Poetry" by the Brazilian Noigandres group credits Mallarmé with "the first qualitative jump: 'subdivisions prismatiques de l'idee', ('blancs')" and the use of "typographical devices as substantive elements of composition."24 Emma Kafelanos writes: "For Mallarmé, particularly in his later poetry, the doctrine of purification of the word implies a conscious rejection of all the words (and ideas) that are customarily associated with that word ...."25 The afore mentioned statements refer to Mallarmé's long visual poem, "Un coup de dés n'abolira le hasard" published in 1887, one year before his death. Erik Slagter writes: "Dsarmee had het niet meer te vernietigen toeval z' $n$ intree in de poëzie gedaan. "26 In this poem Mallarmé used a variety of type faces and letter sizes spread out over the page.27 Mary Ellen Solt expresses Franz Mon's idea when she writes: "Mallarmé's 'Un coup de dés,' returned surface to literature as 'a constituative element of the text'. "28 Kessler states: "Hier sind zum ersten Mal Möglichkeiten für eine spätere konkrete 
Dichtung angelegt: visuelles Element als Bedeutungskomponente, Mitarbeit des Lesers und eine gewisse Mehrdeutigkeit . "29

The Futurists, who took up Mallarmé's ideas, are the ones who inspired Dedaism, according to Slagter. 30 In 1912 the Futurists created a new type of poem under the motto "Parola in Liberta." Their "Manifesto tecnico della letteratura futuristica" was published in May 1912. The manifesto appeared in German translation in the widely read Oerman magazine "Der Sturm." The author, Filipo Tomaso Mar inetti, declared himself in fovor of free typographical arrangement and the abolition of traditional sentence structure and verse forms. 31 According to Peter Weiermair, "Parole in Liberta" means: "Sprengung der Syntax, Freisetzung der Einzelvokabel als provokativer Akt." 32

Before discussing the Dadaists, the east Prussian poet Arno Holz needs to be mentioned. Harald Harting writes that Helmut Heißenbüttel would like to establish Arno Holz as the "patriarch" ("Erzvater") of modern poetry because Heisßenbüttel claims Arno Holz' concern in literature was the method rather than the theme. 33 Solt states that Holz impressed Oomringer because Holz assumed "the freedom to interfere with the arrangement of language, and even more so, that he concerned himself ... with every minute particular both in the visual arrangement of script and in the organization of sound." 34 Hartung sees a certain attempted start of the experimental literature in the "lyrics" of the "Sturm," especially in the work of August Stramm and in the attempts of the Dadaists. He writes: "Dada ist sozusagen ein negatives Experiment, der Versuch, etwas freizulegen, die Blockierung durch Tradition aufzubrechen. "35

The Dada movement started in 1916 in Zürich, Switzer land. The Dadaists experimented with many different kinds of poems. They wrote poems without logical content, made poems consisting of sound effects (bruïtism), and produced poems where background noise happened simultaneously with the recitation of the poem. For their collages they cut up newspaper articles, mixed the cutout words and put them back together at random. 36 Moreover they wanted to use as many letters as possible, 37 The opening up of space and filling it anew with new material is what makes the Dadaists forerunners of concrete poetry. ${ }^{38}$ Kessler writes: "Alles was bei DADA der konkreten 
Dichtung ähnlich ist, weist auf eine direkte Vorläuferschaft des DADA-ismus hin, sofern Vorläuferschaft nur bedeutet:'Freisetzen von Möglichkeiten und Bewusstsein'.."39 According to Hartung, the ideas of Kurt Schwitters and Hans Arp were expanded in concrete poetry. 40 Oumpel explains that: "Dada explored language at an intermedial level by seizing on the various material assets it had to offer outside of generating meaning." 41 She further writes that the influence of Hans Arp on concrete poetry is evident "in the utilization of the 'word' and in his conception of 'random chance'." 42 Guillaume Apollinaire's contribution to concrete poetry is his bundle of poems called "Calligrammes," published in 1918. Most of these poems are written without rhyme or punctuation marks, and some convey their content through their shape. 43 "Apollinaire greift auf das emblematische Gedicht des Barocks zurück," according to Weiermair. ${ }^{44}$ However, the "calligrams" break with the tradition of "solidly filling a form with words ... of earlier poetry." 45

The theory of the concrete movement was set forth by the Dutchman Theo van Doesburg in his pamphlet "Art Concret" in 1930. Yet the concept goes back to 1917 when van Doesburg and Piet Mondrian founded "De Stijl." The "Stijl" group included a wide range of artists, from architects and painters to industrial designers. 46 They formulated ideas which have influenced concrete and conceptual art up to the present. Siegfried J. Schmidt explains the concrete theory which Doesburg first applied to painting as follows: "Die im Bild präsentierten Begebenheiten sind identisch mit dem was sie zeigen: sie zeigen sich selbst, stellen sich selbst dar." 47 Oumpel states: "They stressed reduction to simple straight lines and sharp angles as well as use of only three primary colors and three non-colors ... for painting. As such they applied compositional rigor to their art forms as did Comringer later for the constellation." 48

With all these new concepts at their disposal, the concrete poets expanded and combined them into their own innovative experimental poetry. Following the example of the Dadaists, who discarded old traditions in art and literature, the concrete poets combined Mallarmé's concept of typographical innovation, Holz' freedom of syntax and Doesburg's ideas of concrete art with their own aim to pur ify the language, to start the concrete poetry movement. 
NOTES

1 Dick Higgins, Beorge Herbert's Pattern Poems: In Their Tradition (West Olover : Unpublished Edtions, 1977), p.4.

2 Dieter Kessler, Untersuchungen zur Konkreten Dichtung (Meisenheim am Glan: Ver lag Anton Hain, 1976), p.24.

3 Erik Slagter, ød. Visuele Poëzie: Een bloemlezing konkrete en visuele gedichten (Brussel:

Manteau, 1977), p. 5.

4 Kessler, pp. 27,28

5 Higgins, D. 6.

6 Kessler, pp. $36,37$.

7 Higgins, p. 8

8 Kessler, pp.39, 40.

9 Kessler, p. 46.

10 Kessler, p. 42.

11 Kessler, p. 46, 52.

12 slagter, p. 5.

13 Higgins, p. 4.

14 Slagter, p. 5.

15 Kessler, p. 53.

16 Roder ich Feldes, Das Wort als Werkzeun (Göttingen: Otto Schwarz \& Co., 1976), p. 37. 
17 Christian Wagenknecht, "Proteus und Permutation: Spielarten einer poetischen Spielart," Text + Kritik, No. 30, (1971), p. 1.

18 Wagenknecht, p. 1.

19 Wagenknecht, p. 2.

20 Wagenknecht, p. 5.

21 Wagenknecht, p. 5.

22 Wagenknecht, p. 9.

23 Kessler, p. 54.

24 Augusto de Campos, Decio Pignatari, Haroldo de Campos, "Pilot Plan for Concrete Poetry," in Concrete Poetry: A World View, ed. Mary Ellen Solt (Indiana Univ. Press, 1968), p. 71.

25 Emma Kafelanos, "Pur ification of Language in Mallarmé, Dada and Visual Poetry," West Coast Poetry Review 5, No. 3 (1979), p. 51.

26 Slagter, p. 6.

27 Slagter, p. 27.

28 Mary Ellen Solt, ed. Concrete Poetry: A Worid View (Indiana Univ. Press, 1968), p. 18.

29 Kessler, p. 55.

30 Slagter, p. 27.

31 Slagter, p. 6.

32 Peter Weiermair, "Zur Geschichte der visuellen Poesie," in Konkrete Dichtuna: Texte und Iheorien, ed. Dr. Siegfried J. Schmidt ((München: Bayerischer Schulbuch Verlag, 1972), p. 12. 33 Harald Har tung, Experimentelle Liter atur und Konkrete Poesie (Oöttingen: Vandenhoeck \& Ruprecht, 1975), p. 25.

34 solt, p. 8.

35 Hartung, p. 26.

36 Slagter, pp. $6,7$.

37 Kessler, p. 60.

38 Slagter, p. 8. 
39 Kessler, p. 59.

40 Hartung, p. 28.

41 Liselotte Gumpel, "Concrete" Poetry from East and West Bermany: The Lanquage of

Examplarism and Experimentalism (New Haven: Yale Univ. Press, 1976), p. 48.

42 Gumpel, p. 54.

43 Slagter, p. 17.

44 Weiermair, p. 13.

45 Richard Kostelanetz, ed. Imaged Words \& Worded Imeges (New York: Outerbridge \& Dienstfrey, 1970), n.p.

46 Gumpel, pp. 44, 45.

47 Dr. Siegfried J. Schmidt, Elemente einer Textpoetik: Theorie und Anwendung (München: Bayer ischer Schulbuch Verlag, n.d.), pp. 92-94.

48 Gumpel, p. 45. 


\section{CHAPTER II}

\section{CONCRETE POETRY TILL 1970: THEORIES}

Concrete poetry is more than a continuation and expansion of the ideas and innovations of its precursors. It is a conscious effort to make language itself the subject of poetry. Solt writes: "The concrete poet seeks to relieve the poem of its centuries-old burden of ideas, symbolic reference, allusion and repetitious emotional content; of its servitude to diciplines outside itself as an object in its own right for its own sake." 1

Artists of many different backgrounds initiated the concrete poetry movement. Eugen Comringer was a poet, Decio Pignatari an industrial designer, Hansjörg Mayer a typographer, Heinz Gappmayr a designer and Friedrich Achleitner had studied architecture. Their common aim was to experiment with language and to "create an innovative poetry which advocated a complete break with tradition. 2

The experimental, innovative poetry is the concrete poetry referred to in this thesis. It is the concrete poetry of the West. Concrete poetry from East Germany remains a "lyrical" poetry with the term "concrete" used "to foster Marxist-Leninist solidarity through literature ...."3

In 1943 Carlo Belloli created his "Testi-Poemi Murali" ( Woll Text Poems"). ${ }^{4}$ Belloli's poems, according to Kessler, could be considered concrete poetry even though they were not called that. The term "concrete poetry" had not been coined yet. Emmett William's anthology contains poems from Belloli which can not be distinguished from concrete poetry. 5

Belloli set for th his theories in the introduction to "Testi-Poemi Murali." He also related his poems to "certain necessities of language made evident by existence following the war." Some of Belloli's theories resembled those of Gomringer and the Noigandres group. Thus according to 
Belloli: "the key-words of typographical construction aim at the greatest possible economy of expression." About his poems he writes: "they do not create analogies, they do not invite compar ison. My text pœems neither evoke a state of mind nor do they tell a story. "6

The first poet to use the term "concrete poetry" was the Swede Öyvind Fahlström. He wrote his "Hätila Ragulpr på Fåtskliaben. Manifest für Konkrete Poesie" in 1953. The manifesto already contains many of the ideas later set forth in the manifestoes by Oomringer and the Noigandres group. Fahlström writes: "Den Wörtern ist ein symbolischer Gehalt schon gegeben; dies ist aber kein Orund, warum man nicht die Poesie, ausgegangen von der 'Sprache als konkrete Materie,' er leben und 'schaffen' können sollte." He goes on to say, "Am besten ist es, wenn Form und Inhalt als eine Einheit wirken." 7 Fahlström discusses the fact that a poem can be read up and down and from left to right and right to left.

Fahlström's manifesto was essentially meant to apply to concrete music. "Wenn ich das Wort konkret verwendet habe, geschah dies mehr in AnschluB an konkrete Musik als an Bildkonkretismus im engeren Sinn." Fahlström was aware that concrete poetry, ever though it was an innovative concept, did have precursors. "Außerdem ist der konkret arbeitende Dichter natürlich mit den Formalisten und Sprachknetern aller Zeiten, mit den Griechen, mit Rabelais Oertrude Stein, Schwitters, Artaud, und vielen anderen verwandt."8 Yet Fahlström's manifesto was not influentual in the development of concrete poetry. It circulated only in mimeographed form until it was published in 1966. Neither Oomringer nor the Noigandres group were aware of Fahiström's manifesto at the time when they were developing their own theor ies. 9

The concrete poetry movement had its beginning in 1955 when Eugen Oomringer met Decio Pignatari at the Hochschule für Gestaltung in Ulm, Germany. In 1954 Oomringer had published "vom vers zur konstellation, zweck und form einer neuen dichtung." Pignatari, a Brazilian teacher of industrial design and communication theory, was the leader of the Brazilian Noigandres group. Other members of the group were the poets Haroldo and Augusto de Campos. 10 During the meeting in Ulm, Oomringer and Pignatari agreed to call the new poetry, which they 
each had developed independently, "concrete poetry." In December of 1956 Comringer wrote a preface "konkrete dichtung" for a planned anthology with the same name. 11

A second meeting was held in Ulm in 1956. This time Gerhard Rühm and Friedrich Achleitner from the Viennese group also participated. At the time of the second meeting there existed already some disagreement about the term "concrete." Achleitner and Rühm found the label 'concretist' too limiting."12 According to Kessler, many poets turned away from the name "concrete" soon after it was chosen. ${ }^{13}$ Solt writes: "Most poets will accept the label 'concrete' in its broad definition, very few in its narrow. "14

The early years of the development of concrete poetry are character ized by a profusion of theor ies set forth by the poets. In "From Line to Constellation" ("vom vers zur konstellation") Oomr inger writes: "our languages are on the road to formal simplification, abbreviated, restricted forms of language are emerging. ... so the new poem is simple and can be perceived visually as a whole as well as in parts." 15 The name "constellation" Gomringer took from Mallarmé's poem, "un coup de dés" ( 1887).

rien n'aura lieu

excepté

$$
\text { peut-être }
$$

une constellation 16

Gomringer states: "The constellation is the simplest possible kind of configuration in poetry which has for its basic unit the word, it encloses a group of words as if it were drawing stars together to form a cluster." He also emphasizes the fact that the constellation is not only an arrangement but "at the same time a pley-area of fixed dimensions." 17

Bomringer is fascinated by the word. He writes about it:

es ist eine größe. es ist-wo immer es fällt und geschrieben wird. es ist weder gut noch böse, weder wahr noch falsch. es besteht aus lauten, aus buchstaben, von denen einzelne einen individuellen, markanten ausdruck besitzen. es eignet dem wort die schönheit des materials und die abenteurlichkeit des zeichens. es verliert in gewissen verbindungen mit anderen worten seinen absoluten charakter. das wollen wir in der dichtung vermeiden. ... wir wollen es keinem stil unterordnen, auch dem staccato-stil nicht. wir wollen es suchen, finden und hinnehmen. wir wollen ihm aber auch in der 
verbindung mit anderen worten seine individualität lassen und fügen es deshalb in der art der konstellation zu anderen worten. 18

Gomringer was in Ulm from 1954 to 1958 as secretary to Max Bill at the Hochschule für Gestaltung. Max Bill had studied at the Bauhaus art center at Dessau from 1927 till 1929 and was now applying the "Bauhaus idea of multidimensional art" in UIm. ${ }^{19}$ Gomringer writes: "It can be seen that the work of Max Bill, particularly his analytical thinking, greatly influenced our first intuitive attempts." 20 Before 1954 Gomringer studied in Bern, Switzerland where he was acquainted with graphic artists Diter Rot and Marcell Wyss, publishers of "spirale," a magazine for literature, sculpture, graphics, architecture and industrial design. 21

In 1956 Comringer wrote "konkrete dichtung," a preface to an anthology of the same name which never materialized. Instead, the work appeared in a series of booklets called "concrete poesie poesia concreta" which were published irregularly between 1960-1965. 22 In "konkrete dichtung" Oomringer again emphasizes that concrete poetry is a rational poetry. "It will not serve as a valve for the release of all sorts of emotions and ideas but will consist of a linguistic structure closely related to the tasks of modern communication ..." 23 Gomringer's ideas spread to poets in many other European countries.

In Brazil the Noigandres group was formed in 1952. August de Campos' "poetamos" ("a set of poesia concrete") was published in 1953. Gumpel writes: "Therefore the term 'concrete' had already appeared elsewhere in conjunction with literature, while it was still confined to the visual arts in UIm."24 In December of 1956 the Noigandres group held a large exhibition of concrete poetry at the Museum of Modern Art in São Paulo. 25

The Noigandres group published their "Plano-Piloto para Poesia Concrete" in 1958. The "Pilot Plen for Concrete Poetry" contains "a synthesis of the theoretical writings of the Noigandres group from 1950-58." Their concrete poem is an "Ideogram: appeal to non verbal communication." In addition to visual arts the Noigandres include music in their "Pilot Plan."26 They used the term "verbovocovisual" for a word that "has simultaneously a verbal, vocal and a visual positional value." 27 Furthermore, the "Pilot Plan" stresses that the concrete poem "deals 
with communication of forms, of a structure content, not with the usual message of communication." 28 Despite world-wide contacts the concrete poets in Brazil maintained their own tradition and they were the only group which created concrete poetry with sociologicalpolitical content. 29

The first works of the concrete poets were published in magazines and other small publications which emphasized not only literature but also sculpture, graphics, architecture and industrial design. 30 According to Solt, "concrete poetry, then relates less to 'literature' and more to earlier developments in the field of architecture, painting, sculpture, industrial design ...." 31 Slagter writes that the birth of the concrete poem is strongly related to the cultural partner swap between the plastic arts (beeldende kunst) and literature in the twentiest century." 32

Besides the Swiss magazine "spirale" similar magazines started to appear. The Darmstadt Circle (a group of concrete poets) published the magazine "mater ial." In Stuttgart Hansjörg Mayer (typographer) published "Futura" pamphlets and "portfolio-anthologies of concrete poetry."33 Max Bense (professor of science and philosophy at the Technische Hochschule in Stuttgart) published "augenblick" from 1955-61. Together with Elisabeth Walther he edited the series "rot." Concrete poets from other countries had their work published in these magazines. 34 Thus it is evident that Germany and Switzer land played an important role in the advancement of concrete poetry.

The shortlived Darmstadt Circle consisted of leader Daniel Spoerri, the German dramatist Claus Bremer and the American Emmett Williams. The Darmstadt Circle was important because it was the first to publish an anthology of concrete poetry, "material 1," in 1959. The publishing of "mater ial I" was significant because it indicated early the need for "Sammlung, Zusammenfassung, Überschaulichkeit," according to Kessler. 35

In the winter 1959/60 the first exhibition of concrete texts in Europe was held at the Technische Hochschule in Stuttgart. 36 Here it was Max Bense who clarified and expanded the theory of concrete poetry. In "Zur Lage," published in 1964, he and Reihard Döhl claim that 
instead of poetry based on the traditional syntactical order new language structures had been developed through new divisions in syntactic and semantic dimensions. The new poetry was a poetry "der Wörter, des Setzkasten, der Farben, der Töne." It can be divided into different groups which Bense and Döhl classify as follows:

1 Buchstaben $=$ Typenar rangements $=$ Buchstaben - Bilder

2 Zeichen $=$ graphisches Arrangement $=$ Schr ift - Bilder

3 serielle und permutationelle Realisation = metr ische und akustische Poesie

$4 \mathrm{Klang}=\mathrm{klangliches}$ Arrangement $=$ phonetische Poesie

5 stochastische und topologische Poesie

6 kybernetische und materiale Poesie.

They admit that many of these forms do over lap.

As criteria for the new poetry they mention exper iment and theory, demonstration, model, pattern, play, reduction, permutation, iteration, random, serie and structure. Bense and Döhl claim that the new poetry is not based on expression of feeling but rather on rational use of theor ies. "Anstelle des Dichters-Sehers, des Inhalts- und Stimmungsjongleurs ist wieder der Handwerker getreten, der die Materialen handhabt, der die materialen Prozesse in Gang setzt und in Gang hält." 37 The name "concrete pœetry" is not mentioned, instead they use the term "new poetry."

Gomringer speaks about an invitation to the reader to actively take part in a play activity when reading a poem. Max Bense writes in his article "concrete poetry" of 1965, "concrete poetry does not entertain." He says, "it holds the possibility of fascination," which in his words "is a form of concentration, which includes perception of the material as well as the apperception of its meaning. "According to Bense, concrete poetry is a "style of mater ial poetry." He describes it also as "Design in words. Text design." 38 According to Gumpel, Bense stated in "Aesthetica" that his goal was not to "represent" and "reduplicate" what was already there but rather to "present" and "produce" anew. 39 
Hansjörg Mayer was a typographer who became interested in concrete poetry and who had realized already that "optische Bestaltung" can also be poetry. 40 Mayer created many typographical designs. His "pikto-typografie" deserves to be counted in the "grundlehre" of concrete poetry, according to Gomringer. 41

Franz Mon, according to Solt, "sees a need for returning the poem to the visual meaning it lost when printing standardized the page and writing became 'a mere function of sound'." 42 Mon writes about script (writing): "... daß sie einmal bildhafter natur war und ihre bildcharaktere vielleicht über die lautsprache hinausgehende bedeutungen vermittelten ist vergessen." In his "surface poetry" ( "poesie der fläche") Mon explains that even the smallest text turns the surface into a text basis and that the surface, "center, edge, top, bottom, right and left" takes on meaning and becomes part of the text. The text particles gain their value from that system of coordinates. "Die flöche nötigt vielmehr dazu, den text von ihr her zu denken." 43

Mon pushes the idea of reduction of language even farhter than Gomringer by breaking up the word into particles or letters. "a single letter of a certain size at a certain position on a surface of certain size can be a text." In "texte in den zwischenräumen" the text is found in the negative areas between fragmented letter forms. Mon used torn posters and cut-up newspapers for his "plakatentexte" and writes thus about them:

... traditional meanings and common syntax have evaporated in the cur iosity about 'spaces'; a cur iosity directed not only towards the fragmentation of letters and their regrouping along a cut but toward the whole, also towards the behavior of the paper, for instance the appearance of fibers in between the torn letters, the laying bare of covered surface. Once the convention which converts script instantly into sound and their meaning has been abandoned, everything is drawn into the suction of the newly forming structure: in combination with fragmented letters, a fold or a tear suddenly acquires the function of punctuation. Cutting lines ... take on syntactical functions like space and spaces ...."44

"Im lesen vermehrt sich unablässig der gegenwärtige text durch den bereits gelesenen," Mon claims in regard to the collages. 45

Ferdinand Kriwet is well-known for his "Rundscheiben" ("Round Disks"). Kriwet explains the difference between "schreibetexte" and "schrifttexte." "Schreibetexte" are "Sehtexte" 
which create tension between the optical and intellectual reading. "Schrifttexte" only utilize the typographical possibilities of mechanical script. 46

In contrast with the German and Swiss concrete poets the Austrians formulated very few theories. The Viennese group existed from 1953 to 1960. Its members were Gerhard Rühm (composer), Friedrich Achleitner (architect), Oswald Wiener (jazz musician) and the poets H.C. Artmann and Konrad Bayer. 47 They opposed the old stifled cultural traditions, the provincialism of Austria.

Rühm was the only member of the Viennese group who wrote down his theories. One was the theory of "der methodische inventismus," a methodical woy of writing poetry which should enable everybody to write poetry. 48 In his description of a collage Rühm uses the term "montage" to emphasize the distinction between concrete poetry and the poetry (collages) of the Dadaists. Rühm sees the "montage" as a "Nevordnung von Sprachelementen, meist einfachen Sätzen ... die zufällig vorgefundenen oder gezielt gewähten Quellen entnommen sind, und zwar eine Neuordnung nach primär poetischen Gesichtspunkten." A montage becomes a constellation of simple sentences. 49

In 1959 Achleitner, Rühm and Artmann produced an anthology of dialect poetry. According to Gumpel, "These dialect endeavors were rather interesting, because they demonstrated an unusual combination of elitist avant-gardism and interest in the local Viennese 'Volksmund,' ... which had previously found expression through the 'Wiener Yolkstheater'."50 Kessler explains that dialect poetry is not "Heimatdichtung" but rather sound poetry. 51

Ernst Jandl of Vienna and Heinz Gappmayr of Innsbruck did not belong to the Viennese group. Jandl is of the opinion that a certain method of creating a poem should only be used once. Thus the poem is "identified with the method in which it was made." Gappmayr considers "concrete" to mean "all conditions of language." 52

The "Position I du Movement International" drafted by Pierre Garnier of France and signed in 1963 by poets from Germany, Austria, England, Belgium, Brazil, Scotland, Finland, France, Holland, Japan, Portugal, Switzer land, Czechoslovakia and the United States, not only emphasizes 
the internationality of the experimental poetry but also how far and how quickly it had expanded from the original constellation and ideogram.Because they all had points in common, the different kinds of poetry were grouped together, by Garnier, under the "general name Spatial (which includes concepts of time, structure, energy)." The following quote is part of "Position I of the International Movement:"

$\begin{array}{ll}\text { concrete poetry: } & \begin{array}{l}\text { working with language mater ial, creating structures with } \\ \text { it, transmitted primarily qesthetic information } \\ \text { the word or its elements taken as object and centers of } \\ \text { visual energy }\end{array} \\ \text { visual poetry: } & \begin{array}{l}\text { pictorial, graphic, sculptural and musical arrangement due } \\ \text { to the collaboration of painters, sculptors, musicians and } \\ \text { typographers } \\ \text { based upon the phonemes, sound bodiesof language and } \\ \text { generally speaking upon all sound emitted by the vocal } \\ \text { organs of man, worked out on the tape recorderand tending } \\ \text { toward the creation of spatial sound. } \\ \text { the poem composed directly on magnetictape, words and } \\ \text { sentences being takenas objects and centers of auditory } \\ \text { energy }\end{array} \\ \text { phonic poetry: } & \end{array}$

In the discussion of concrete poetry a distinction is often made between the poetry of the early phase (classic c.p.) and the poetry of the later years. Döhl sees 1960 as the first "Höhepunkt" in the history of concrete poetry. He calls the time before 1960 "die relativ strenge Phose (der Konstellation) ...." The years between 1960 and 1970 were the years of expansion with strong tendencies "zum engagierenden und engagierten Text." 54 Hartung writes "Auf die ersten Theoretiker folgten die Spaßmacher und Exzentriker." 55

At the end of the sixties works by Achleitner, Bremer, Bomringer, Rühm, Mon and Jandl that had or iginally appeared in small publications were now gathered in anthologies and published by such publishing houses as Rowohit, Luchterhand and Walter. 56 Gomringer writes about the changes in concrete poetry:

Innerhalb der Konkreten Poesie selbst haben sich ... eine ungeohnt große Zahl von Ausdrucksformen herausgebildet. Ihre Anthologien sind wahre Bilderbücher geworden. 
Die Konkrete Poesie oder besser gesagt die Methode der Konkreten Poesie erstreckt sich auf gesellschaftskritische Poesie, auf Vietnam und Biafra, auf HippyArrangements, auf Analogien zum grafischen Computer Design, auf das Buchstabenbild, auf die nackte Künstlerische Präsentation typographischer Materialien, ausschließlich auf rein grafische Bildmittel überheupt. 57

Does all this indicate then that concrete poetry is dead? There are indeed statements to that effect. In a Dutch manifesto, published in 1978 by Hans Clavin, Gerrit Jan de Rook, Herman Damen and Robert Joseph, concrete poetry is declared dead. The poets claim poetry can no longer remain detached from society as a purely aesthetic poetry. They seek the combination of poet, language and reality. "De poëzie moest op het podium, op de barricade, op de straat." 58 They only declare the aesthetic poetry dead, but concrete poetry is much more than that.

It is true, the pure concrete poetry, which "extracts from language an essential meaning structure and arranges it in space as an ideogram or a constellation--as a structural word design- within which there are reticulations or play-activity" has been expanded. If we look at it in a broader sense, as innovation, a new use of language, combination of arts and literature, then we must disagree with the doomsayers and agree with Belloli:

The people of the future will not

seek poetry in libraries but on the

walls of their rooms, and they will

find in it an integrating factor

uniting them with the environment

in which they work. 59 
NOTES

1 solt, p. 1.

2 Gumpel, p. xi.

3 Gumpel, pp. xi, xii.

4 Solt, p. 37.

5 Kessler, pp. 15, 23.

6 Solt, p. 37.

7 Öyvind Fahlström, "Hätila Ragulpr på Fåtskliaben: Manifest für Konkrete Poesie," in Text Buchstabe Bild, introd. Felix Andreas Baumann (Zürich: Zürcher Kunstgesellschaft, n.d.), p. XVIII.

8 Fahlström, p. XXII.

9 Kessler, p. 23.

10 Kessler, p. 150.

11 Stephan Bann, ed. Concrete Poetry: An International Anthology (London: London Magazine Editions, 1967), p. 7.

12 Gumpel, p. 38.

13 Kessler, p. 150.

14 Solt, p. 7.

15 Eugen Gomringer, "From Line to Constellation," trans. Mike Weaver, in Concrete Poetry: A World View, ed. Mary Ellen Solt (Indiana Univ. Press, 1968), p. 67.

16 Eugen Bomringer, "vom vers zur konstellation," in konkrete poesie: deutschsprachige autoren, ed. Eugen Oomringer (Stuttgart: Philipp Reclam Jun., 1972), p. 153. 
17 Oomringer, "From Line to Constellation," p. 67.

18 Gomringer, "vom vers zur konstellation," p. 157.

19 Gumpel, p. 37.

20 Eugen Bomr inger, "Max Bill and Concrete Poetry," trans. Irène Montjoye Sinor and M.E.S., in Concrete Poetry: A World View, ed. Mary Ellen Solt (Indiana Univ. Press, 1968), pp. 68, 69. 21 Hartung, p. 36.

22 Kessler, p. 162.

23 Eugen Gomringer, "Concrete Poetry," trans. Irène Montjoye Sinor and M.E.S., in Concrete Poetry: A World View, ed. Mary Ellen Solt (Indiana Univ. Press, 1968), pp. 67,68.

24 Gumpel, p. 38.

25 Solt, p. 13.

26 Augusto de Campos, Pignatari, Haroldo de Campos, "Pilot Plan for Concrete Poetry," p. 72.

27 Max Bense, "Concrete Poetry," trans. Irène Montjoye Sinor and M.E.S., in Concrete Poetry: A World View, ed. Mary Ellen Solt (Indiana Univ. Press, 1968), p. 74.

28 Augusto de Campos, Pignatari, Haroldo de Campos, "Pilot Plan for Concrete Poetry," p. 72.

29 Kessler, p. 152.

30 Hartung, p. 28.

31 Solt, p. 11.

32 Slegter, p. 6.

33 Solt, pp. 16, 17.

34 Oumpel, p. 37.

35 Kessler, pp. 135, 136.

36 Reinhard Döhl, "Konkrete Literatur," in Sonderdruck aus Deutsche Geoenwartsliteratur: Ausganospositionen und aktuelle Entwicklingen, ed. Manfred Durzak (Stuttgart: Philipp Reclam Jun., n.d.), p. 288.

37 Max Bense, Reinhard Döhl, "Zur Lage," in Text Buchstabe Bild, introd. Felix Andreas Baumann (Zürich: Zürcher Kunstgesellschaft, n.d.), pp. XXXYIII, XXXIX. 
38 Bense, "Concrete Poetry," p. 73.

39 Gumpel, p. 43.

40 Kessler, pp. 33, 34.

41 Eugen Oomringer, ed. konkrete poesie: deutschsprachice autoren (Stuttgart: Philipp Reclam Jun., 1972.), p. 7.

42 solt, p. 18.

43 Franz Mon, "zur poesie der fläche" in konkrete poesie: deutschsprachige autoren, ed. Eugen Gomringer (Stuttgart: Philipp Reclam Jun., 1972), pp. 168, 169.

44 solt, p. 19.

45 Franz Mon, "zur poesie der fläche," in kankrete poesie: deutschsprachice autoren, ed. Eugen Gomringer (Stuttgart: Philipp Reclam Jun. 1972), pp. 168, 169.

46 Kessler, p. 132.

47 Solt, p. 21.

48 Hartung, pp. 36, 74, 75 .

49 Volker Hage, "Rückblick auf die Konkrete Poesie: Ernst Jandl und Berhard Rühm," in Die Wiederkehr des Erzählers (Frankfurt a M., Berlin, Wien: Ulistein, 1982), p. 44.

50 Gumpel, p. 43.

51 Kessler, p. 142.

52 solt, p. 21.

53 Pierre Garnier, "Position I of the International Movement," trans. Irène Montjoye Sinor and M.E.S., in Concrete Poetry: A World View, ed. Mary Ellen Solt (Indiana Univ. Press, 1968), p. 67.

54 Döhl, p. 292.

55 Hartung, p. 288.

56 Döhl, p. 288.

57 Berold van der Auwera, "Theor ie und Praxis Konkreter Poesie," Text + Kritik, No. 30 (1971), pp. 40, 41 .

58 Slagter, pp. 13, 14, 53 .

59 Solt, p. 37. 
CHAPTER III

\section{DEMONSTRATIVE ANALYSES}

At the end of the sixties the term "concrete poetry" covered a wide range of poetry. Gomr inger gives the definition of ideogram, constellation, dialect poetry, palindrome, typogram and pictogram. Mon defines "textbilder" and "collagen." 1 Schmidt divides the poems in his text book into concrete poetry and visual poetry (with four subcategor ies). 2 Kessler gives ; the most elaborate classification of the different forms of concrete poetry.

1 Concrete Poetry

(1) still with sentences

(2) multiple word forms (constellations)

(3) one word forms

(4) kinetic poetry (poetry book idee, [ in which the turning of the page plays an important role])

(5) mixed forms (transition to visual poetry)

2 Visual Poetry

(1) ideogram-visual constellation

(2) typogram

(3) pictogram

(4) transition to graphics and other border line forms

(5) mixed forms

5 Acoustic Poetry

(1) phonetic poetry

- with words

- with sounds

- speaking sounds

- other human sounds

(2) phonic poetry

- unprocessed

- processed

(3) electronic acoustic poetry

(4) mixed forms $\mathrm{m}^{3}$ 
Solt states that "the new experimental poetry can be classified as visual, phonetic (sound), and kinetic." 4

Schmidt, Kessler and Solt all differentiate between concrete poetry and visual poetry. Kessler defines concrete poetry in terms of being mainly concerned with the word, visual poetry being concerned with both word and space. 5 solt writes that visual poetry" is a word design in a designed world." As a logical reason she cites the fact that both Oomringer and the Noigandres group were involved in graphic design at the time when they were experimenting with their new poetry. Pignatar $i$ was a designer who became a poet but Gomringer and the de Campos brothers were "poets who became word designers because the old world of the traditional poem was no longer their world." 6

And yet, in many instances concrete poetry and visual poetry are considered the same. According to Gumpel, "visual" poetry is a recent synonym "applied to literary concretism. " Döhl writes that concrete and visual literature are again and again used as synonyms for each other. 8 Gomringer sees visual poetry as an expansion of concrete poetry. He writes:

By introducing the notion 'visual poetry' the medium-conscious concrete poet drew the attention to the artificiality of the 'written' in any form. The notion of 'visual' poetry focused anew on our interest in traditional forms of singular signs (letters, punctuationmarks, elementary symbols, signs for cypher, etc.) as being 'Gestalten'(figures?), in order to interpret them anew and to poetize them freshly ....

He continues: "After several spatial systems of patterns were established the graphic-iconic element became more and more independent." 9 Thus it is clear that concrete poetry and visual poetry are in many ways over lapping and as such can be used as synonyms for each other.

A concrete poem does not represent anything, therefore it can not be interpreted the same way a traditional poem is interpreted. The form and the "Gedichttechnik" are important components of a concrete poem. Therefore the need exists to recognize how a poem is constructed and why it is put together in a certain way. 10 Then it is up to the reader/peruser to interpret the 
poem according to his/her world of experience. It is, in the words of Oomringer, "an invitation." 11

Each of the following poems was chosen as a representation of a certain group of poems. Definite boundary lines between the different categor ies can not always be established. Some poems may be a combination of two different types of poems, others can contain elements of many categor ies. They "may resemble an ideogram as compositional unit $(y)$, a Constellation as rhematic connex, a palindrome in its capacity for multidimensional reading, a typogram in its graphemic physiognomy, a pictogram in its iconic foundation." 12

The poem "baum kind hund haus" by Gomringer is a constellation--"the word group" which "replaces the verb"-- 13 and according to Gumpel, it is "his purest permutation."14 Oomringer does not classify a permutation as a separate category. He does recognize "daß die kombinatorik ein hilfsmittel der konstellation ist: ein direkter einfluß auf die dichtung war der mathematik nie möglich." 15 A permutation realizes the complete range of a text by arranging the words of a text in different combinations so that the reader can create his own associations between the words. 16

baum
baum kind
kind
kind hund
hund
hund haus
haus
haus baum
baum kind hund haus

In "baum kind hund haus" the title gives four words (the material) without semantic cohesion. Each word consists of four letters. The four words appear in four groups and the first 
word of each group is repeated twice. The process goes on till all four words have been used according to their original order. At the end the "four segments are lined up again suggesting permutation can start over again." 17 The permutation thus creates a circular movement.

The use of only nouns without attributes leaves the interpretation wide open. Rühm explains the reason for not using attributes. He claims the description "a blond lady with blue eyes" reduces the range of interpretation and phantasy considerably. If only the word "lady" is used the reader is free to imagine any lady. ${ }^{18}$ The reader becomes "a collaborator and in a sense the completer of the poem. 19

Thus in "baum kind hund haus" the reader can choose his type of tree, and the child by the tree can be his favorite image of a child. The dog is by the child, then by the house. The last group shows the house by the tree and the poem is complete. The repetition of the first word in each group suggests a rather quick movement. The dog moves from the child (by the tree) to the house and the child moves with the dog. The "individuals" dog and child move between the "location" tree and house. 20 Tree and house form the per imeter between which the action takes place. Reading the poem backwards (upwards) reverses the motion. The fact that the poem can be read backwards is a "special feature" ( "ein besonderes merkmal") of the constellation. 21

The progression of circular movement is also suggested by the sound. Baum kind, kind hund, with the same ending, hund, haus, alliteration and in haus, baum, the inner sound connects the end to the beginning of the poem again. The constellation, which at first sight looked as if it were a simple mathematical arrangement of words, is a "play area of designated size" and a challenge to the reader to use his own creative thought process. 22

The palindrome also can be read backwards. Here the pœem does not function because of semantic content, but because of the word, sentence of verse being exactly the same in both directions,. The meaning can remain the same or it may change. 23 The two palindromes by André Thompkins are self explanatory. 
"STRATEGY; GET ARTS' 24

Alfred Liede even considers the following poem by Gomringer a palindrome. 25

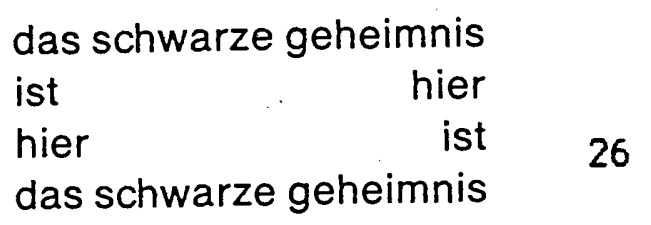

If a palindrome only trades on the fact that words, sentences or verses are the same when read from left to right or right to left and top to bottom or bottom to top there is not much for the reader to experiment with. It does not stimulate the imogination nor does the reader need to complete it. Therefore the palindrome is a weak example of concrete poetry.

"Rot anstatt rot" is an ideogram by Achleitner, an Austrian architect, who was a member of the Viennese group. The poem appeared in the Viennese anthology "as one of 'Four Constellations'." Gumpel classifies "rot anstatt rot" as a "vertical application of a (closed) ideogram. " 27

$$
\begin{aligned}
& \text { rot } \\
& \text { anstatt } \\
& \text { rot } \\
& \text { anstatt } \\
& \text { rot } \\
& \text { anstatt } \\
& \text { rot } \\
& \text { anstatt } \\
& \text { rot } \\
& \text { anstatt } \\
& \text { rot } 28
\end{aligned}
$$

The poem consists of the word "rot" ("red") and the preposition "anstatt" ("instead of"). At the iconic level the words are lined up at the left side forming an almost solid line, with the "rot" at top and bottom containing "anstatt." At the acoustic level the reading of the poem creates a rhythmic cadence which could continue indefinitely. At the semantic level the ideogram is closed. The "rot" at the end prevents the circular movement which is evident in "baum kind hund haus." 
Had the poem ended with "anstatt" the circular movement of the permutation would have been possible. Ending the poem with "anstatt" would also have changed the meaning because then the substitution could have been anything besides "rot." The semantic "linking function of the preposition": "anstatt" is realized, though "not with logical coherence," in that it "causes a selfinduced serialization that continues under its own momentum, making the other five elements of 'rot' unfold from the five 'anstatt'. "29

The formula $X$ instead of $Y$ forms the basis for the serialization. Such a besis is absolutely absurd because both $X$ and $Y$ represent red and not substitution takes place, render ing the formula useless. Schmidt calls this an example of how easily our think and speech patterns can be questioned. 30

Is Achleitner's ideogram a vertical shape which can be read in both directions( up and down), the ideogram by Heinz Gappmayr, an Austrian designer from Innsbruck, is hor izontal and can be read only in the traditional woy from left to right. On the pure iconic level the weight of the word "sind" at the right creates the balance for all three words on the left and as such seems to contain all three. Yet the dark line eradicates the "sind" at the right and consequently the other three, contained in it, at the same time. The text is presented as follows: "optisch fal3bar auf eine weiße Fläche, in einem Raum gesetzt, der zum Text gehört und die formen von 'sind' inhalltlich mitbestimmt. "31

$$
\text { sind }
$$$$
(\sin \alpha)
$$$$
\text { asind }
$$$$
\text { "sind" }
$$

On the semantic level the poem "embodies Cartesian thinking/being in pluralized form through 'sind,' the finite verb for 'being' denoting 'are'," sccording to Gumpel. 33 In addition to the 
spatial design on the page, linguistic signals also help determine meaning. The first "sind" is simply being, identifying. The "sind" in parenthesis is an insecure being, maybe it should be there, meybe not. The "sind" with quotation marks is a secure statement, an affirmation. The last "sind" negates all former three and "sind" is no more. It could be considered a life poem., the first "sind" representing childhood, the second one adolescense, the third middle age and then finally death. Gumpel describes "sind" as a "laconic-iconic depiction of death," because it ends in death. 34 Schmidt sees the last "sind" as negative but he leaves the interpretation of "sind" in parenthesis open and suggests it could stand for addition, restriction or possibility. 35 "Sind" constitutes on of the most subtle visual works and it closely follows Gappmayr's theory: "The text is a fixed connection between thought and reality, a unity of concept and design. " 36

The next ideogram is neither vertical nor horizontal but rather diagonal, with reading possibilities in many directions. Oomringer's "wind" does not only give the impression of letters scattered across the page by the wind, it aiso embodies wind better than a poem about wind.

Upon closer examination what seems like scattered letters forms a well-balanced shape held together by the two "W":s at the bottom and at the top. The word "wind" can be read in four straight lines which could be analogous for $S, W, E$, or $N$. The wind is not always $S, W, E$, or $N$. It can be SW, NE, etc. The poem also shows 7 more possibilities to read wind.

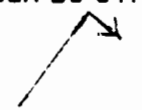<smiles>[CH]C[CH]</smiles>

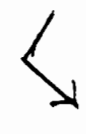

$\searrow$
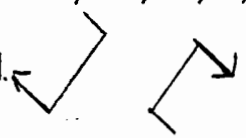

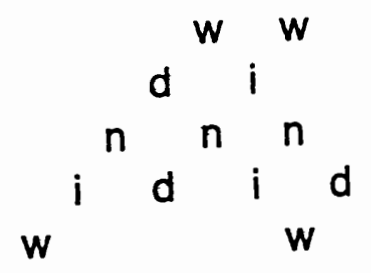

38

The poem then, is wind, in its capacity to be read in many directions. The poem also shows the result of wind. In the words of Solt: "The letters actually seem to float as if the wind were acting upon them. "39 "Wind" is an ideogram. It makes its content visible by integrating graphic 
elements and surface area. The next poem, a pictogram by Döhl, simply "shows its lexical meaning." 40

"Apfel" by Reinhard Döhl is probably the best known concrete poem. Some call it the best example of concrete poetry, others use it as an anti example. "Apfel" is a pictogram and also a tautology because content equals shape. A tautology is a "zweckfreie ästhetische Spielerei ohne sprachkritische oder gar linguistische Dimension," according to Feldes. 41 Rühm calls "Apfel" an anti example and writes: "mit konkreter Poesie aber haben solche harmlosen Späßchen nicht viel zu tun." With "Späßchen he is referring to the replacement of the word "Apfel" with "Wurm." 42 Kessler uses the poem to distinguish between a visual poem ("Apfel") and a pure concrete poem

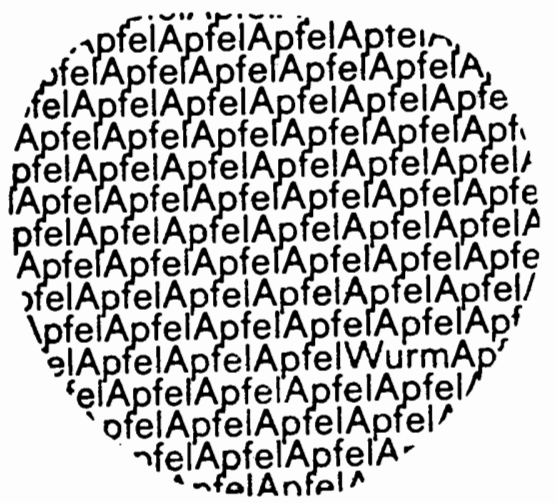

where the visual aspect does not become the most important feature. He refers to "Wurm" as a kind of cheap joke, but at the same time he credits Döhl , a member of the Stuttgart group, with being an expert in the field of concrete poetry. 44 The apple looks like a shape cut out of material not a shape filled with letters because then the letters would not be cut off at the outline. The arrangement of the word "Apfel" gives a well-balanced texture with " $f$ " and " 1 "building the vertical and "A" the diagonal lines. The reason for the use of the capital " $A$ " instead of the lower case rounded "a," which would fit in better with the rounded shape of the apple and the "p" that follows it, is the fact that the inverted " $A$ " is repeated in the " $W$ " of Wurm. The unexpected "Wurm" ("Worm") in the apple is, according to Gumpel, "a rather realistic depiction of how the substance of the apple had been eroded by the worm making its home in the fruit." 
The worm constitutes the "play" in the pictogram. It points out the importance of paying attention to the "very substance of the printed word" instead of only looking at the iconic and sementic interrelationship. 45 Döhl's "Apfel" is a pictogram and tautology. The poem "Panzer" by Claus Bremer is also a pictogram, in which the shape is recognized first, but it can not be classified as a tautology because the semantic value of its content is in disharmony with the shape.

Bremer's poem "Panzer" ( "tank"), an instrument of war, is constructed out of the text of the "Sermon on the Mountain." Here is a juxtaposition of ideas which invites the reader to take a position. The shape of the poem questions the content and content questions shape. 46 is war justified? Is religion the answer? Can a tank be used to gain the justice referred to in the

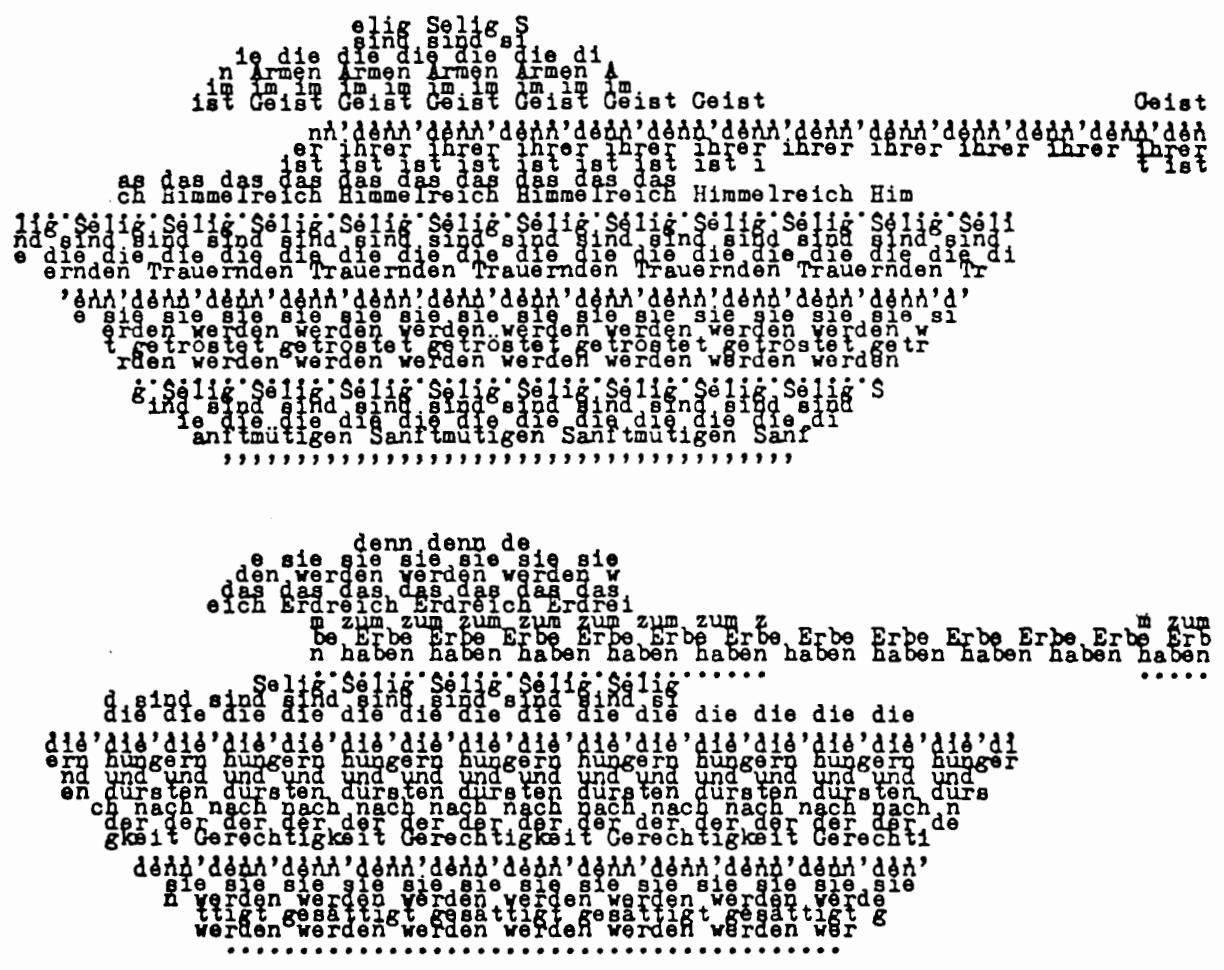

47

the "Sermon?" The poem leads to reflections about Christianity and its message in modern times. It also questions the position state-church. 48 The pictogram "Panzer" gains its strength from the contrast between icon and semantic content. Therefore it is more than a mere tautology. 
"Lesbares in unlesbares übersetzen" is a typical example of many of Bremer's poems in which the text visually completes the action of the semantic content. Felix A. Baumann refers to this type of poem as a "text about a text" or in other words "eine kleine Poetik des konkreten/visuellen Textes. "49

Bremer, a dramatist, studied philosophy, literature and art history at the Universities of Hamburg and Freigburg. From 1957 till 1959 he belonged to the Darmstadt circle and from 1962 till 1965 he was guest lecturer at the Hochschule für Oestaltung in Ulm. 50

The translation of "lesbares in unlesbares übersetzen," which is "rendering the legible illegible," appears in Emmett Williams' Anthology of Concrete Poetry. 51 The first line of the poem states the action.

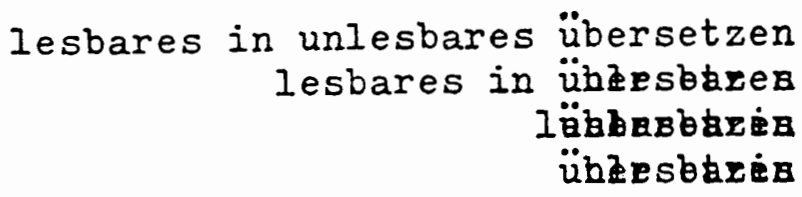

The process is completed in the next three lines. Each line is reduced by typing the last word "übersetzen" over the preceding ten letters or spaces till the last line is completely illegible. However, the "ü" from "übersetzen" remains clearly visible as a reminder of the action which just took place. In this poem the use of the typewriter constitutes an important element not only because it is part of the process, but also because it would be hard to obtain the same effects in the letterpress. 53 "Lesbares in unlesbares übersetzen" is strictly a poem about itself. It does not refer to anything outside the text. It does not symbolize anything, it refers to language only.

Ferdinand Kriwet created the following "sehtext." What stands out the most is its visual shape and as such it is similar to the pictogram. However there exists no relationship between the shape and the words that fill the shape. Form and text do not contradict each other as in Bremer's "Panzer" and the sehtext is not a tautology either. Rühm writes that Döhl would probably have filled this shape with the word"Karussell." 54 
The form of the Round Disk is "open; its beginning and end are both fictitious," which indicates the possibility of continued circular reading. 55 Gumpel compares this to the circular movement of permutations. "Kriwet's forms make these factors visually conspicuous." Round Disk (Rundscheibe) IV is titled "Rolled-up Journey" ("Aufgerollte Reise"). The concentric rings are composed of geographical names and are divided in a "main' and 'subsidiary' motif," according to the difference in type 56 The reason for the use of different letter sizes is "to employ the possibilities of lettering in its widest sense productively and not just reproductively... to stimulate new exper ience in language," according to Kriwet. 57

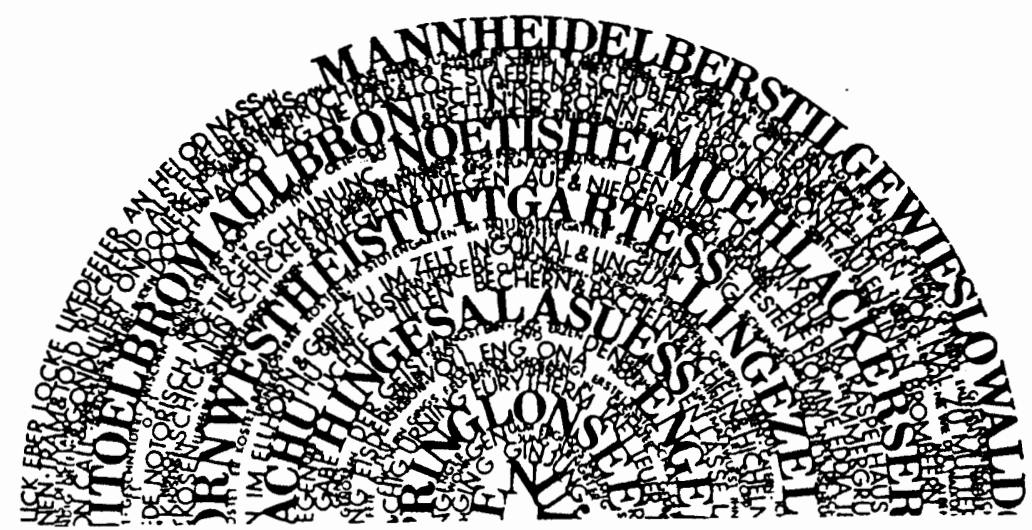

Part of IV

In his book leserattenfänge Kriwet gives a detailed "Zeile für Zeile und Wort für Wort" explanation of his Round Disks. 58 Gumpel describes his systematic procedure as going from "syllabic emancipation," "vowel exchange" and "syllabic permutation," to "translation." She does find the "poetic catalog" helpful in decipher ing the text. Providing a reading guide for a poem is far removed from the or iginal aim of the concrete poets. Kriwet's "Round Disk" represents an instance of "excessive experimentation," yet is original in design and different from any other type of concrete poetry. 59

Using a variety of letter cases the way Kriwet does, is not new in concrete poetry. The typogram also emphasizes letters. The poem "jetzt" ("now") by Gerhard Rühm, a composer and "one of the most adventurous of the 'Wiener Gruppe' during the fifties,"60 is clessified as a 
typogram by Bumpel because of its "trading on different lettercases. "61 Stephan Bann gives it the name "placard/poem" because the poem reveals itself the best when read at eye level.

The difference in meaning becomes obvious when one compares the "jetzt" in Gomringer's anthology, in which it takes up the whole page, with the one in Williams' anthology, where it is printed at the bottom of the page. Situated at the bottom of the page the poem loses part of its poster function. It does not catch the eye as easily because the reader first needs to skim over the empty white space before he reads the poem. The word "jetzt" weakens and loses its urgencey of the present (now). 62 (see next page)

The different positioning of the poem on the page emphasizes the importance of composition. In Williams' placement of "jetzt" the white from the top of the page seems to gain too much importance. In the first example "jetzt" utilizes the compolete expanse of the page and affirms Mon's theory about the importance of the "fläche" and consequently edge, top, bottom, left and right, as "textkonstitiante. "63

jetzt Jetzl

Jetzt

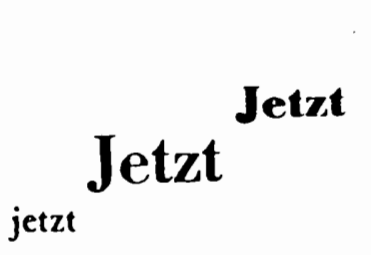

jełzt

jetzt

jetzt

jetzt

jetzt

64 
Gerhard Rühm (1958)

jetzt $=$ now

jetzt

Jeizt

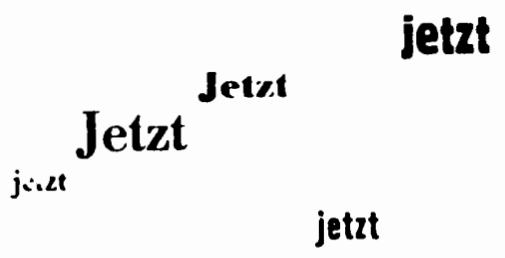

\section{jetzt}


Each "jetzt" gains a different value depending on its typographic arrangement and position on the page. The individual "jetzt"s "come and recede through optical illusion of thick-large, thinsmall type,"65 and each identifies a "unique moment of time."66 The bold letters suggest a present "now" and the light ones a "now " of the past or future. The slanted "jetzt" seems to create a flowing motion which could imply an indefinite continuation of "now."

In "jetzt" the words are grouped in such a way that they create diagonal lines. In "tu" the diagonal lines are more prominent. They are formed by single letters. Thus, "tu" is a better representation of a typogram--the most reduced form of visual poetry67--than "jetzt." "Tu" was written (designed) by Diter Rot in 1956. It presents the "pœetic material" for each reader to use as he pleases without interference from the author's subjectivity. Daniel Spoerri described the poem as "Two squares, inter locking, form at their intersection the two little words'ut' and 'tu.' A possible interpretation would be that there is no meeting without reciprocal influences. "68 Gumpel explains that "tu" is "you" in French and also that it is "etymologically rooted in the number two,"

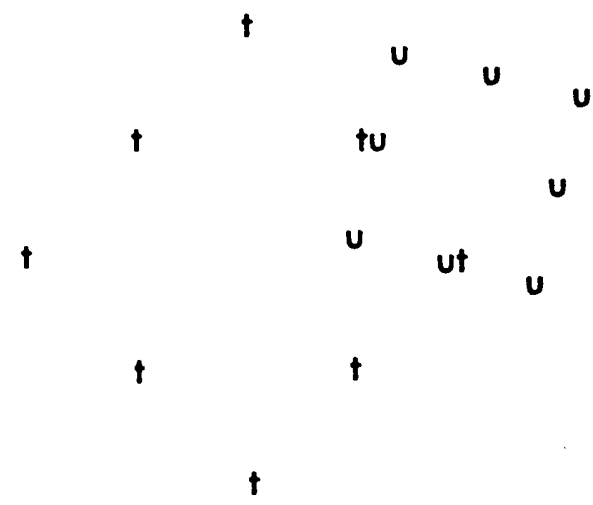

\section{9}

the number two," (a fact the writer has not been able to substantiate) which should refer to the two diamonds. She further mentions the faint possibility of translating the "ut' as Latin 'to/in order to'." The poem illustrates "how dependent verbal formation is on design, since the 'tu' bears little significance without the larger planemetric distribution. "70

Solt sees "tu" as a "death poem" because "'tu' ('you') turned around becomes 'ut' ('do' of the musical scale)-'you' translated to another state. 71 At the iconic level the death poem could be 
construed from the six "t"s which look like crosses in a cemetary. Thus even the reduced form of concrete poetry is open to many interpretations. If poetry crosses into the area of aesthetic typography, the interpretations cease and only the aesthetic aspect remains.

From the typogram, which uses single letters, it is but a small step to the following letter structures by Hansjörg Mayer, called "pikto-typografie" by Oomringer. 72 Mayer, "one of the most original of the younger designers and typographers," studied at the Technische Hochschule in Stuttgart with Max Bense and was a member of the Stuttgart group. 73
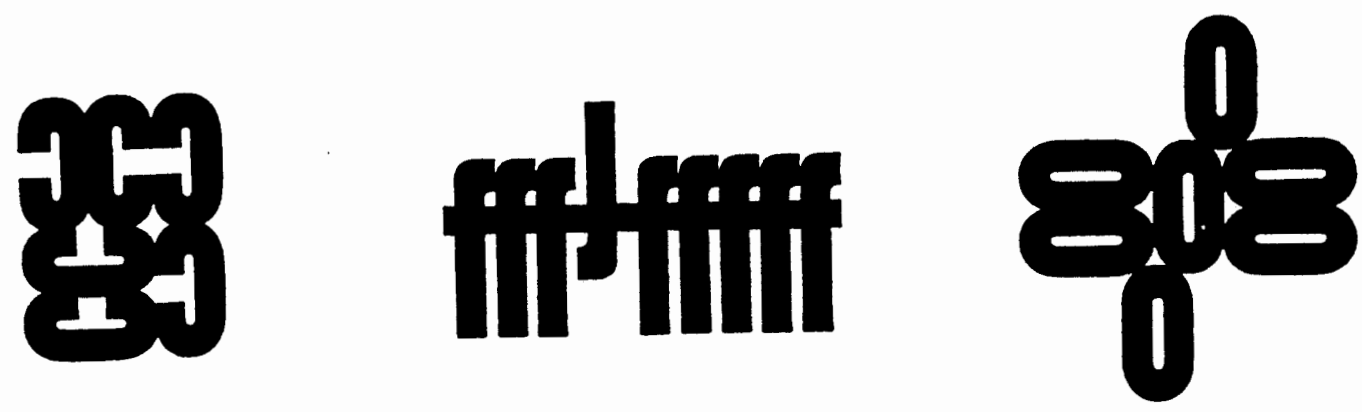

74

The examples here are part of the "alphabet," created by Mayer in 1962, for which he used "the bold condensed 'akzidenz grotesk'" type face. 75 Bann points out that "these typographical designs are not Concrete Poetry, at least not in the stricter sense of the term." He further states that Mayer "is not concerned with meaning: the letters he uses are not so much legible as supremely visible." 76 Locher and Broos share Bann's opinion. They consider the "alphabet" "autonomous typography" because the typography is no longer functional (making "the text as clear and legible as possible"). Therefore, "autonomous typography is aesthetic typography." According to Locher and Broos, "printed letters and paper are no longer used as instruments for conveying information but as materials with which an object can be made." In these letter structures the visual shape of the letters stands out the most, thus showing the "graphic possibilities of the letter." Locher and Broos credit Bense with pointing out that in some structures the shape of the letter becomes intensified, for example the " 0 ," in others the original 
shape is not easily recognized anymore, especially if the letter stands independently from the rest of the alphabet like the "Z." 77

The " $\mathrm{C}$ " structure is put together in such a way that the white inside the letter no longer functions as mere background but takes on its own independent shape. Even though the individual letter loses part of its identity in the group structure, the structure never becomes a "complete abstract shape." "... it continually refers back to the letter shape from which it has been built. 78

Thus the letter remains intact. Mayer's letter structures fit Oomringer's definition of a typogram. Gomr inger states: "typogramme sind ergebnisse eines besonderes intensiven eingehens auf die buchstabengestalt ... poesi entdeckt sich in buchstaben, verändert sie und verändert ganze textbilder die dadurch gleichzeitig dichterisch interpretiert werden. "79 Yet others like Bann, Locher and Broos call them "autonomous typgraphy." In the following poem Haroldo de Campos provides the best answer to the question "poetry or typography?" especially since the poem refers to Mayer's letter structure.

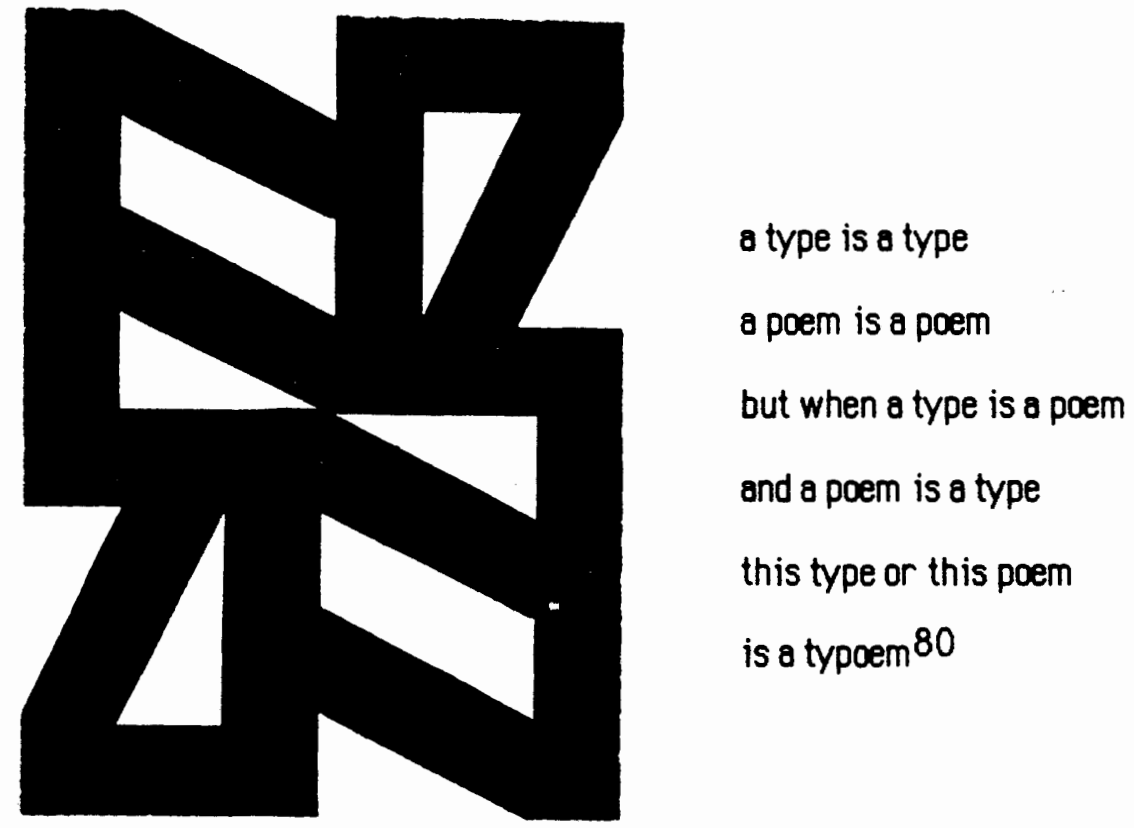

The last poems discussed here are by Ernst Jandl. Jandl studied Germanistic and English at the University of Vienna and has taught at grammar schools in Vienna since 1949.81 He did not 
belong to the Viennese group although his ideas closely resembled those of Rühm and Artmann concerning the need "to move as far as possible from traditional poetry. 82

The first poem is what Norbert Lynton called "a very nice visual-cum- linguistic joke." 83 A triangle of "e"s is filtered through a

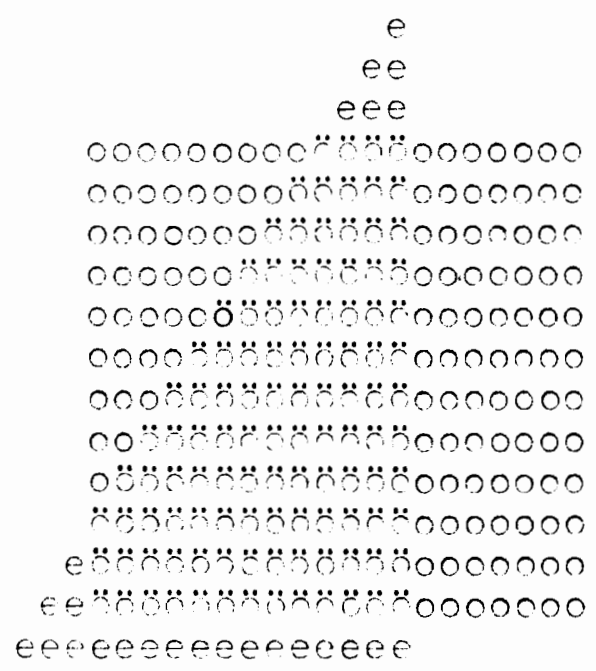

rectangle of "o"s. Where the two meet they become "o." The umlauts on the "o"s darken the triangle enough to give the visual impression of the over lapping of triangle and rectangle. Linguistically the "œe" combination makes an "ö." As such it could also be considered a sound poem.

In the poem "schtzngrmm" the emphasis is not on the visual shape but rather on the sounds of the acoustic components of the word. Jandl calls it a "Sprechgedicht." "Schtzngrmm" not only appeared in anthologies but was also put on a record. 84 Jandl reduces the word and text to a "Konsonantengerust." The different consonants appear in groups which are repeated or stretched out to evoke sounds. The sounds can be understood only if the reader understands the semantic content of "schtzngrmm," a contraction of "Schützengraben," ("trench") and associates it with war. The $t-t-t-t-t-t$ resembles the sound of a machine gun, tssssssssssss the sound of bullets flying through the air, grrrrrrrr the sound of a (tank) motor. 85 The end of the poem moves from the acoustic level, from the last long drawn out grrr. to the semantic level of $t$-tt which means tot (dead). 


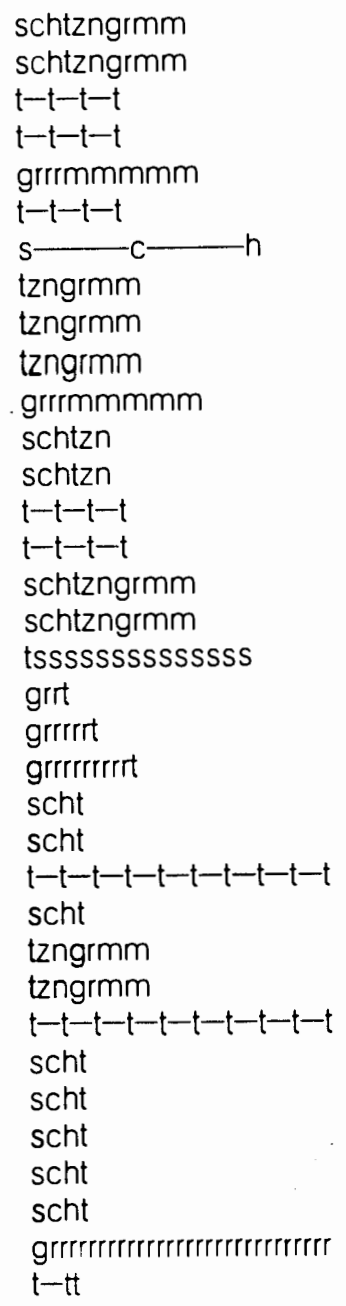

In "schtzngrmm" it is the sounds which refer back to the text and as such "concretize" it. The poem "schtzngrmm," a sound poem, differs from a visual poem because its components are used as acoustic elements raher than visual elements. 


\section{NOTES}

1 Eugen Gomr inger, "definitionen zur visuellen poesie," in konkrete poesie: deutschsprechige outoren ed. Eugen Gomringer (Stuttgart: Philipp Reclam Jun., 1972), pp. 163,164.

2 Siegfried J. Schmidt, "Zur Auswohl und Anordnung der Textbeispiele," in Konkrete Dichtunq: Texte und Theorien (München: Bayer ischer Schulbuch Verlog, 1972), p. 20.

3 Kessler, p. 195,196.

4 solt, p. 59.

5 Kessler, p. 193.

6 solt, p. 61.

7 Gumpel, p. 35.

8 Döhl, p. 270.

9 Eugen Gomringer, "Some remarks on the Notion 'Visual Poetry'," West Coast Poetry Review 5 , №. $3(1979)$, p. 153.

10 Kessler, p. 205.

11 Eugen Gomringer, "From Line to Constellation," p. 67.

12 Gumpel, p. 195.

13 Eugen Gomr inger, "baum kind hund haus," in An Anthology of Concrete Poetry ed. Emmett Williams (New York: Something Else Press, Inc., 1967), n.p.

14 Gumpel, p. 96.

15 Gomringer, "vom vers zur konstellation," p. 158.

16 Franz Mon, "textbilder," in Experimentelle und Konkrete poesie: Vom Barock zur Begenwart.

Qd. Dietrich Steinbach (Stuttgart: Ernst Klett, 1981), p. 108.

17 Gumpel, p. 96.

18 Hage, p. 49. 
19 Eugen Bomringer, in An Antholocy of Concrete POetry, ed. Emmett Williams (New York:

Something Else Press, Inc., 1967), n.p.

20 Gumpel, p. 97.

21 Gomringer, "definitionen zur visuellen poesie," p. 163.

22 Gomringer, "vorn vers zur konstellation," p. 157.

23 Gomr inger, "defintionen zur visuellen poesie," p. 164.

24 André Thompkins, "7 palindrome," in konkrete poesie: deutschsprachice autoren, ed. Eugen Gomringer (Stuttgart: Philipp Reclamuun., 1972), p. 136.

25 Alfred Liede, Dichtung als Spiel: Studien zur Unsinnspoesie an den Orenzen der Sprache (Berlin: Walter de Oruyter \& Co., 1963) Vol.II p. 110.

26 Eugen Gomr inger, "das schwarze geheimnis" in kankrete poesie: deutschsprachige autoren, ed.

Eugen Bomr inger (stuttgart: Philipp Reclam Jun., 1972), p. 60.

27 Gumpel, p. 196.

28 Friedrich Achleitner, "rot anstatt rot," in konkrete poesie: deutschsprachige autoren, ed. Eugen Gomr inger (Stuttgart: Philipp Reclamuun., 1972), p. 9.

29 Gumpel, p. 196.

30 Schmidt, "Zur Auswahl und Anordnung der Textbeispiele," p. 21.

31 Thomas Kopfermann, Fundamentalpoetik und Textpraxis einer Neo-Avantgarde (Frankfurt am Main, Bern: Peter D. Lang, 1981), p. 219.

32 Heinz Gappmayr, "sind" in konkrete poesie: deutschsprachige autoren. ed.Eugen Gomringer (Stuttgart: Philipp Reclam Jun., 1972), p. 42.

33 Oumpel, pp. 198, 199.

34 oumpel, p. 199.

35 Schmidt, "Zur Auswahl und Anordnung der Textbeispiele," p. 22.

36 Heinz Gappmayr, in An Anthology of Concrete Poetry, ed. Emmett Williams (New York:

Something Else Press, Inc., 1967). n.p..

37 Kessier, p. 244. 
38 Eugen Gomringer, "wind," in konkrete poesie: deutschsprachiqe sutoren ed. Eugen Gomringer (Stuttgart: Philipp Reclam Jun., 1972), p. 38.

39 Solt, p. 9.

40 Feldes, p. 22.

41 Feldes. p. 22.

42 Hage, p. 48.

43 Reinhard Döhl, "Apfel" in konkrete poesie: deutschsprachige sutoren. Eugen Gomringer (Stuttgart: Philipp Reclam Jun., 1972), p. 38.

44 Kessler, pp. 133, 254.

45 Gumpel. pp. 204, 205.

46 Döhl, p. 282.

47 Claus Bremer, "Panzer," in Experimentelle und Konkrete Poesie:Yom Barock zur Geaenwart. ed. Dietrich Steinbech (Stuttgart: Ernst Klett, 1981), p. 34.

48 Schmidt, "Zur Auswahl und Anordnung der Textbeispiele," pp. $21,22$.

49 Felix Andreas Baumann, introd. , Iext Buchstabe Bild (Zürich: Zürcher Kunstgesellschaft, n.d.), p. 7 .

50 Eugen Gomringer, ed. konkrete poesie: deutschsprachice autoren (Stuttgart: Philipp Reclam Jun., 1972), p. 26.

51 Emmett Williams, trans., "render ing the legible illegible," in An Antholoov of Concrete Poetry ed. Emmett Williams (New York: Something Else Press, Inc., 1967), n.p.

52 Claus Bremer, "lesbares in unlesbares übersetzen," in kankrete poesie: deutschsprachige autoren ed. Eugen Gomringer (Stuttgart: Philipp Reclam Jun., 1972), p. 29.

53 Bann, p. 10.

54 Hage, p. 49.

55 Solt, p. 20.

56 Gumpel, pp. 113-115.

57 Solt, p. 20. 
58 Schmidt, "Zur Auswahl und Anordnung der Textbeispiele," p.22.

59 Gumpel, p. 117.

60 Emmett Williams, ed. An Anthology of Concrete Poetry (New York: Something Else Press, Inc., 1967), p. 339.

61 Gumpel, p. 202.

62 Gumpel, p. 203

63 Franz Mon, "zur poesie der fläche," in konkrete poesie: deutschsprachice autoren, ed. Eugen Gomringer (Stuttgart: Philipp Reclam Jun., 1972), p. 168.

64 Gerhard Rühm, "jetzt," in konkrete poesie: deutschsprachige autoren. ed. Eugen Gomringer (Stuttgart Reclam Jun., 1972), p. 118.

65 Gumpel, p. 202.

66 Wendy Steiner, "Res Poetica: The Problematics of the Concrete Program," New Literary

History Vol. XXII, 1981, p. 540.

67 Kessler, p. 251.

68 Daniel Spoerri, in An Anthology of Concrete Poetry ed. Emmett Williams (New York:

Something Else Press, Inc., 1967), n.p.

69 Diter Rot, "tu," in konkrete poesie: deutschsprachige autoren, ed. Eugen Bomringer (Stuttgart Reclam Jun., 1972), p. 109.

70 Oumpel, pp. 201, 202.

71 solt, p. 22.

72 Eugen Gomringer, introd., konkrete poesie: deutschsprachice autoren, ed. Eugen Bomr inger (Stuttgart Reclam Jun., 1972), p. 7.

73 Williams, p. 337.

74 Hansjörg Mayer, "alphabet," in Edition Hansiöra Mayer, eds. Hans Locher, Kees Broos (Den Harg: Hoegs Gemeentemuseum, 1968), n.p.

75 Locher and Broos, n.p.

76 Bann, p. 11. 
77 Locher and Broos, n.p.

78 Locher and Broos, n.p.

79 Gomringer, "defintionen zur visuellen poesie," p. 164.

80 Haroldo de Campos, "Typoem," in Edition Hansiöra Mayer, eds. Hans Locher, Kees Broos (Den Harg: Haags Gemeentemuseum, 1968), n.p.

81 williams, p. 336.

82 Solt, p. 21.

83 Ernst Jandl, "o e" in An Anthology of Concrete Poetry ed. Emmett Williams (New York:

Something Else Press, Inc., 1967), n.p.

84 Döhl, p. 276.

85 Kessler, pp. 261-263.

86 Ernst Jandl, "schtzngrmm," in Experimentelle und Konkrete Poesie: Vom Barock zur Gegenwart ed. Dietrich Steinbach (Stuttgart: Ernst Klett, 1981), p. 70. 


\section{CHAPTER IV}

\section{CONCRETE POETRY AND TECHNOLOGY}

Typography plays a very important role in concrete poetry. As part of the printing process typography has benefitted tremendously from technological innovations and from the new ideas which made use of these innovations.

Typography entails the printing process and the arrangement of letters on the page. At the time of Gutenberg's invention of movable type around 1450 both procedures were performed by the printer. With the development of newer and faster printing presses the two procedures remained interwoven and yet developed separately from each other. The printers were mainly concerned with simplifying and speeding up the printing process. The typographer or typographic designer was responsible for letter form and design of the page.

The invention of the printing press is generally attributed to Johann Gutenberg. He devised a method whereby individual letters could be cut once and then cast in unlimited quantities for assembly and reassembly. ${ }^{1}$ This was accomplished by cutting the letter out of hard metal and then pressing it into softer metal to make a sunken impression or matrix. The matrix was put in the bottom of a mold in which then molten lead was poured. When the lead was cold it could be removed and the result was a long shank with a raised reproduction of the letter at the end. 2

These type pieces were arranged, by hand, next to each other in a composing "stick," a strip of wood with corners, held in the hand. Blank pieces of lead were used between words to justify (space) the words in each line. After the printing was completed, the type pieces had to be taken out of the composing stick again. ${ }^{3}$ The printing consisted of inking the raised letter surfaces, putting moist paper on them and then pressing them together. Using this method 
Gutenberg produced about 200 copies of his 42 line Bible between 1452 and $1455 .{ }^{4}$ The same method of printing was used for centuries while mechanization to speed up the process became more refined and hourly output increased.

The first real improvement was the steam-driven stop-cylinder press designed by the German Friedrich Koenig. 5 A major breakthrough came in 1880 with the invention of the linecasting machine or Linotype machine in the United States by the German-born Ottmar Mergenthaler. Both casting and setting are performed by one machine. 6 Linotype casts a solid one-piece line or slug of type at one time from movable matrices. 7 The Monotype, invented by the American Tolbert Lanston in 1885 , casts one letter at a time. ${ }^{8}$ The operation is divided between two machines: a keyboard, resembling a typewriter and a caster. The main advantage of Monotype is its quality of composition. 9

Lithography, invented by Alois Senefelder in 1796, developed into offset printing, a very "popular printing device." Ira W. Rubel discovered "that an image accidentally transferred from the plate cylinder of his rotary to the rubber blanket of the impression cylinder... could itself be used for printing and in fact produced a superior impression. "10

The invention of photography around 1830 soon was incorporated in the printing process. ${ }^{11}$ offset Lithography printing now uses a photographic process. Either a printed text is photographed or transparent matrices are used. ${ }^{12}$ Coldtype is the name of a simple method of preparing a text by a machine that resembles a typewriter. The machine can justify lines in type making allowances for the use of different letters. 13 In 1946 the Frenchmen Higot and Moyrod invented the photocomposing machine, or Lumitype composing machine, which "broke with the tradition of letters cast in lead. 14

Presently there are several different kinds of phototypesetters available. These advanced printing machines have many outstanding features. The composition of a text can now be done on a computer screen. The text is typed and appears on the screen. This provides a better opportunity to experiment. It also eliminates printing something twice due to problems that were not 
anticipated in the first printing. In combination with a computer an electronic phototypesetter can print a Bible in one minute. ${ }^{15}$

Although speed is of utmost importance to the printer there are other advantages which are important to the typographer; namely, the wide choice of typefaces and the "almost unlimited range of creative possibilities." The letters can be "compressed, closed, interlaced, horizontal, vertical, diagonal, staggered, screened, distorted, printed in circular setting etc.."16 Furthermore, there exist the possibilities of "enlargement or reduction" of the text, "stretching a line to make it longer or higher" and delivering the composed text "on paper or film, in negative or positive, for straight reading or reverse reading." 17

The following examples show the versatility of the modern printing process. "Coldtypestructures" by Klaus Burghardt were developed by a previously programmed photographic composing machine, using only one letter. The letter, which was the basic building block of the new structure, has lost its own shape and consequently its own sound and meaning. ${ }^{18}$

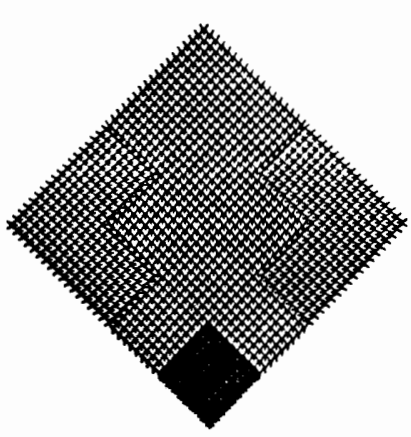

The use of adhesive-backed letters is the one

Carl Dair refers to as "scissors-and-paste-pot method." Letters can be torn, jumbled and almost put together again. 20 Due to modern printing techniques these compositions can be easily printed. "Abstract" is a composition by Franz Mon. The picture seems to be abstract and yet the top line is readable. The word "abstract" has been made concrete.
This is an example of autonomous or aesthetic typography. According to Locher and Broos, concrete poetry becomes strictly visual art, "when the image content -- visual tension between the shape of the letters and the surface of the paper -- dominates at the expense of linguistic content. 19

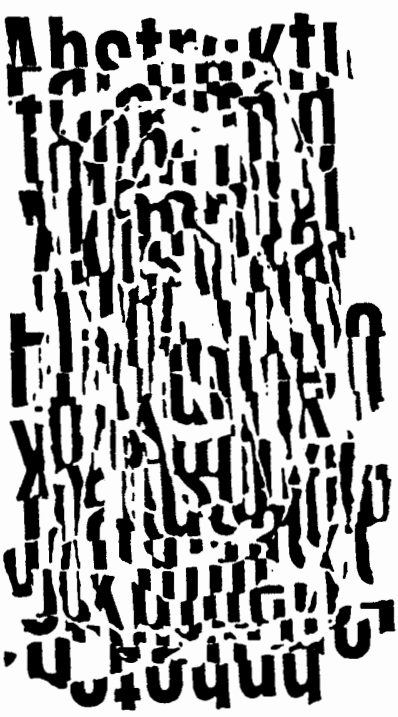


The ability of phototypesetting machines to produce many different letter sizes is illustrated by the print "Schlaf" by Max Bense. His composition is also reduced.

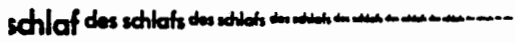

The other "Schlaf" print was produced by Bob Fixott at the Yanquard. He typed the symbol for the required letter size and then the word "schlaf," then the symbol for the next letter size and again the word "schlaf." This was repeated seven more times:

schlafschlafschlafschlafschlafschlafschlafschlafschlaf

"Schlaf" by Max Bense shows a close connection between shape and meaning. The disappearing letters create a picture of drifting off to sleep. 21

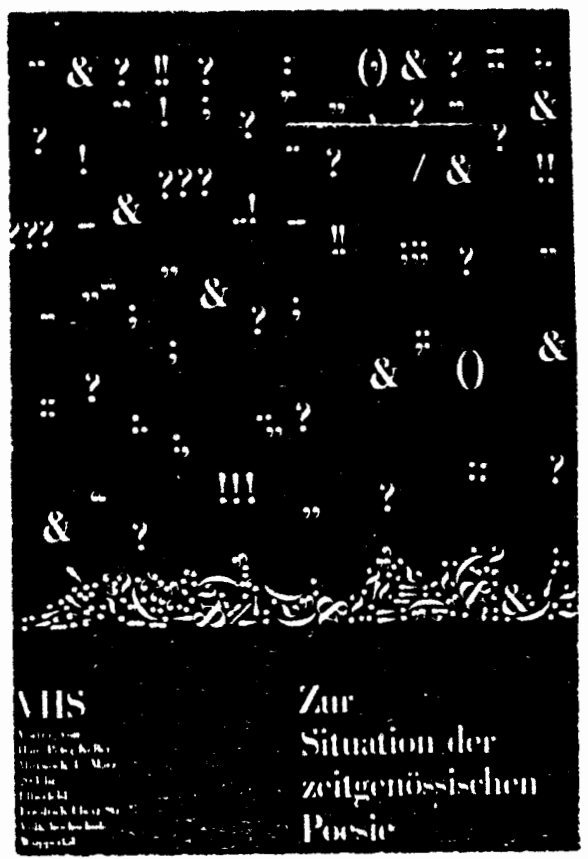

The phototypesetter, which also can deliver the text in the negative, made this print possible. It is an advertising for the Volkshochschule in Wuppertal and was done by Albrecht Ade. 22 The composition shows a literal snowfall of punctuation marks. Even though only punctuation marks are used, it still is functional typography or concrete poetry, because the punctuation marks create an elementof activity and motion, which refers back to the text. 
The computer is not only used to print a text; it can also be programmed to create a text. The example by Marc Adrian uses the linguistic element as the formative component. 23

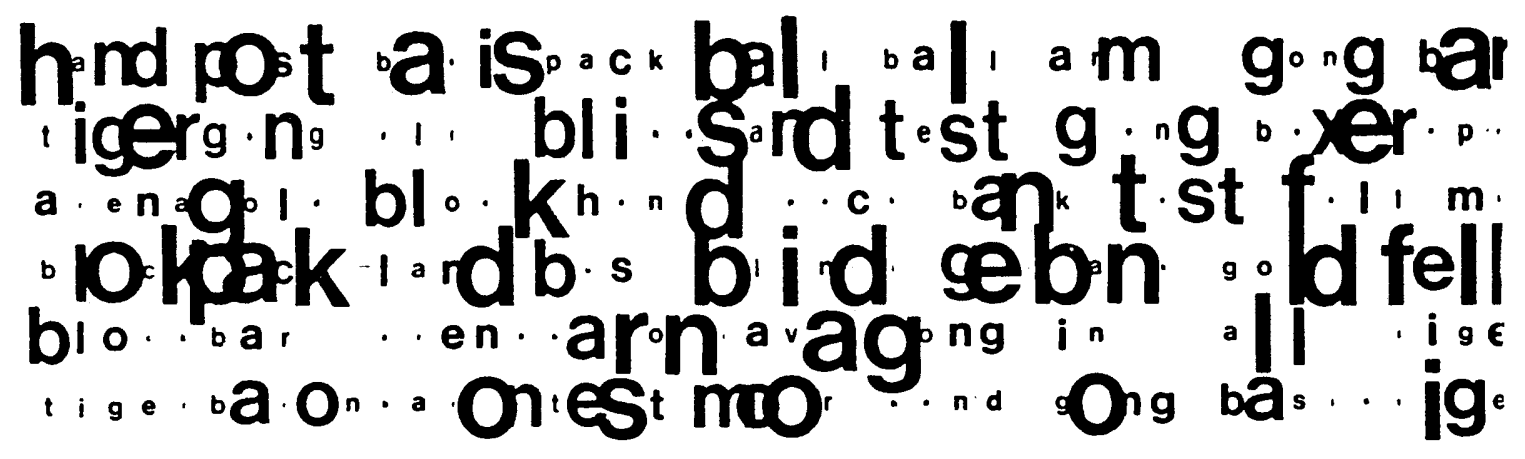

The letters are different in size and in some instances even over lap each other. However, Franke did not indicate whether the letter sizes were chosen at random or what kind, if any, program had been used. But the fact remains that still new avenues are opening up for creating concrete poetry.

The visual poetry is not the only type of concrete poetry that can benefit from the computer. Some of the computer generated poetry is reminiscent of concrete poetry, especially the constellations. There is even a strong similarity between the description of computer generated poetry by its "author" and the descriptions of concrete poetry. According to Louis $T$. Millic the positive aspect of computer generated poetry is "the curious behavior of familiar words in unfamiliar combinations or contexts." 24 Lothar Bornscheuer writes that constellations appeal to a new willingness to read and read out loud, to the enjoyment to discover words anew, to experiment with words. 25 In order to create computer poetry one has to have some mathematical and technological knowledge writes Herbert Franke, 26 and Bornscheuer states that concrete poetry is a mathematical calculation plus creative inspiration. 27 The difference at this time is then that computer poetry is still in its early stage and the random choosing of words can not be controlled enough. Franke writes:

The relatively simple language patterns accessible to contemporary computer poetry are reminiscent of the stylistic means of concrete poetry. This is marked by a restriction to linguistic elements of the utmost simplicity, the breaking-up of relations, the juxtaposition of fragments, and 30 on. If computers are introduced for such experiments, satisfactory results may well follow. 28 
The following two poems can serve as examples. One is the computer-generated poem "Weihnacht" by Rul Ounzenhauser. The words are taken from the semantic concept Christmas. 29 The other one is a constellation by Eugen Bomringer called "worte sind schatten." 30

$\quad$ Weihnacht
Der Schnee ist kalt
und jeder Friede ist tief
und kein Christbaum ist leise
oder jede Kerze ist weiß
oder ein Friede ist kalt
oder nicht jede Kerze ist rein
und ein Engel ist rein
und jeder Friede ist still
oder jeder Friede ist weiß
oder das Kind ist still
ein Engel ist überall

Weihnacht

worte sind schatten

worte sind schatten

schatten werden worte

worte sind spiele

spiele werden worte

sind schatten worte

werden worte spiele

sind spiele worte

werden worte schatten

sind worte schatten

werden spiele worte

sind worte spiele

werden schatten worte

Thus it is evident that technology played an important role in the development of concrete poetry. Although technological progress provided many possiblities for experimentation with text there were other influences which changed typography and consequently benefitted concrete poetry 
NOTES

1 Carl Dair, Desian with Type (Toronto: Univ. of Toronto Press, 1967), p. 45.

2 Dair , p. 45.

3 Robert Lechène, "Printing," Encyclopaedia Britannica: Macropsedia, 1985 ed. XXVI, p. 71.

4 Elisabeth Geck, Johannes Gutenberg (Bad Godesberg: Inter Nationes, 1968), p. 28.

5 Lechène, p. 72.

6 Geck, pp. $71,72$.

7 Lechène, p. 73.

8 Lechène, p. 73.

9 Ruedi Rüegg, Godi Fröhlich, Typographische Grundlagen (Zürich: ABC Edition, 1972), pp. 3036.

10 Lechène, p. 74.

11 Lechène, p. 73.

12 Dair, p. 37.

13 Lechène, p. 79.

14 Geck, p. 81.

15 Geck, pp. $81,82$.

16 Rüegg, p. 41.

17 Lechène, p. 80.

18 Hans Locher, Kees Broos, eds., Edition Hansjörg Mayer (Den Haag: Haags Bemeentemuseum, 1968), n.p.

19 Locher and Broos, n.p.

20 Dair, p. 137.

21 Locher and Broos, n.p. 
22 Doir, p. 112

23 Herbert W. Franke, Computer Braphics, Computer Art, trans. Gustav Metzger (New York: Phaidon Publishers, 1971), p. 51.

24 Louis T. Millic, "The Possible Usefulness of Poetry Generation," in The Computer in Literary and Linquistic Research: Papers from a Cambridge Symposium, ed. R.A. Wisbey (New York:

Cambridge Univ. Press, 1971), p. 180.

25 Lothar Bornscheuer, "Eugen Gomringers 'Konstellation'," in Konkrete Dichtung: Texte und Theor ien (München: Bayer ischer Schulbuch-Verlag, 1982), pp. 127, 128.

26 Franke, p. 8.

27 Bornscheuer, p. 135.

28 Franke, p. 51.

29 Franke, p. 51.

30 Eugen Gomringer, "worte sind schatten" in konkrete poesie: deutschsprachioe sutoren (Stuttgart: Philipp Reciam, 1972), p. 59. 


\section{CHAPTER V}

\section{TYPOORAPHY AND CONCRETE POETRY}

Since its beginning typography has represented the aesthetic element in printing. At the time of Johannes Outenberg's invention typography was the part of printing concerned with creating beautiful letters and manually arranging them in a composing stick. When technological advances changed and improved the printing process, typography became a separate profession. With the new technology at their disposal and under the influence of movements in the visual arts along with the demands of an increased advertising industry, typographers began to design different letters and completely changed the page design.

When Outenberg cut his first letters he patterned them on the manuscript letters. The initial letter of each chapter was painted by hand. Thus the printed page very much resembled a manuscript. ${ }^{1}$ In those early days of printing each printer had his own type which at the same time served as his "trade-mark." During the sixteenth century the first type foundries were developed. They provided printers with type cast from the same matrices. Yet the design of type remained important and many of the type faces used now are based on the letters designed before 1500.2

During the Reformation it became clear for the first time that "printed works could influence people." 3 Indulgences had been printed already in large amounts. Martin Luther's theses, also printed in large quantities, reached many cities throughout Europe within a month's time. ${ }^{4}$ Now printers wanted to produce more and more with the result that quantity soon became more important than quality. The well designed page with beautiful letters started to deteriorate because type cutters tried to save time by copying existing types. Consequently they lost touch with the or iginal sources. 5 
In Germany the black letter remained the basic letter used for printing. It was in France, England and Italy where the new types were being developed. In 1540 the French type cutter Garamond designed a roman type more suitable for mechanical reproduction. 6 Pierre Simon Fournier designed the type face which carries his name. The Didot family created the Didot type face in the middle of the eighteenth century. ${ }^{7}$

The two Englishmen who influenced typography are William Caslon and John Baskerville. In 1734 Caslon designed a refined version of Garamond's roman type face which became widely accepted. John Baskerville expanded on Caslon's design and cut his Baskerville type face in 1757. Baskerville was not only interested in designing type faces. He also concerned himself with matching type, ink and paper in order to get the best possible results. He left more space between letters and tried to emphasize "the typographer rather than the illustrator or engraver." 8

The Italian Giambattista Bodoni further developed Baskerville's idea of page design, but instead of using the Baskerville type he too took his inspiration from the Garmond type and created his own Bodoni type in 1768. "He set what was, in general, to be the standard book style of the world until the appearance of William Morris. "9

The Industrial Revolution caused a general deterioration in all areas of craftsmanship. In printing, fascination with the new and faster printing methods overshadowed æesthetic page design. Cost became an important factor and competition eroded the quality of books even more. 10

From 1890 to 1920 it was the "Private Press Movement" which rekindled the interest in fine book printing. In England William Morris, who owned the Kelmscott Press, brought back the black letter and the beautiful page design. The Doves Press was established by T.J. Sanden and Emery Walker. The Kelmscott Press and the Doves Press each had their individual style. Morris was known for his beautiful decorations. Books from the Doves Press were attractive in their simplicity of design, relying only on "type, spacing and presswork" without any decoration or illustration.

In the Netherlands it was S.H. de Roos who designed books and was "one of the earliest of the new school of typographers, who provided layouts for the publisher or printer, specifying 
type format and overall design." As the printing process became more specialized "the typographer, trained in industrial design or graphic arts, succeeded the printer or the publisher in deciding on how a book should look." 11

There were other challenges for the printers. In the 19th century they were for the first time confronted with the demands of a growing industry, demands "associated with the distributing and marketing" of an increasing amount of new products. 12 Until this time typographers had been mainly concerned with printing books. Now they were challenged in new areas such as advertising. Advertising requires a different typographic approach than book printing, because the text must not only be easy to read, it also has to draw attention. Instructions accompanying new products have to be short and convey their message in a strictly functional manner. 13

The typography of advertising showed a lack of style and an abundance of ornamentation in the late 1800 s. Many different type faces were used regardless of whether they formed a well designed page. In the twentieth century advertising agencies were established which hired independent designers. 14 Thus typography had become a profession separate from the printing process. Schools of design were established with the aim "... to promote artistic, creative and design talents and to impart scientific, technological and vocational know ledge. 15

The Dadaists and Futurists were the first to innovate a completely new typography after World War 1. Their pages exploded with letters and letter fragments without regard for horizontal lines or margins. 16 it was Jan Tschichold who tried to bring order in the typographic hodge-podge of the early 1900s. He published "die Neue Typographie" and "Typographische Bestaltung" in 1925. To Tschichold, "The purpose of all typography is communication." He saw communication already in terms of international communication, a view he has in common with the concrete poets. He wrote: "Types with definite style characteristics or nationalistic flavor, like Gothic, Fraktur, or 'Kirchenslavic,' are not simple enough in form and tend to restrict the possibilities of international communication. ". 17

Another strong influence on typograpty came from the Bauhaus school, founded by the architect Waiter Oropius in 1919. The fact that many of the instructors of the Bauhaus School 
were architects and industrial designers showed in the demands they put on their typography; types had to be used "like the buildings and machines they disigned, " they had to "be sharp and unornamented, symbolic of a machine-dominated society." 18 The Bauhaus influence provided the impetus to search for a new, simpler letter without ornamentation to distract from its function, in order to create a functionally arranged text. The typographers wanted a letter whose typographical shape would stand in direct relationship to the text. 19

Different sans serif (originally called Orotesque) type faces were designed for this purpose. Herbert Bayer, a typographer and instructor at the Bauhaus, designed the Universal type in 1925. Rudolph Koch designed the "Kabel" and Paul Renner published "Futura" in 1927.20 Futura seemed to fulfill the requirements of the typographers best because it is an extremely simple symbol, an exclusive functional reading instrument and is used by many typographers and concrete poets. 21

Did concrete poets use typography, typographers began to make use of concrete poetry. Dair writes: "... the development of concrete poetry has shown promise of opening up new avenues of thought for typographic designers." 22 Tschichold writes: "The purpose of all typography is communication. Communication must be made in the shortest, simplest, most definite way." 23 Dieter Urban explains the task of the communications designer. It is:

the planning, designing and realization of visual and/or verbal messages, which are conveyed to specific target groups by means of different maedia. The contents are of a commercial, cultural, social, political or religious nature. Forms or expression can be instructive, commercial or artistic/sesthetic. 24

But whatever the task of the communications designer is, he will need typography. Urban emphasizes the importance of typography: "... it is precisely the expressive possibilities of typography that lift reading material above the level of pure message-delivery to 'presentation'; the reader becomes an 'interpreter' ...."25

The following two examples show how the different movements, Dadaism, Bauhaus functionalism and even poetry, have been combined to create outstanding designs, compositions, 
concrete poetry. The designs are a group of students from the School for Design in St. Gallen. They were created for the cover of "Typographical Monthly" and appeared in the magazine "Novum Gebrauchsgraphik". The basis for the assignment was "poetry," or "word interpretations raised to the level of visual poetry. 26

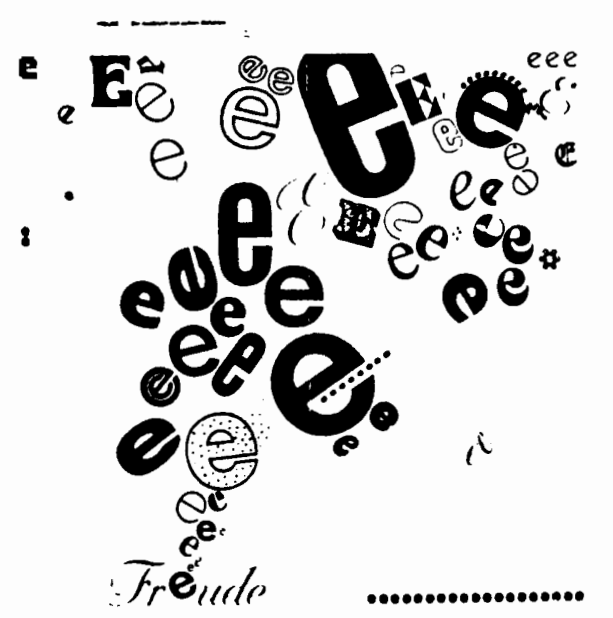

Freude- "Joy The explosion of real feelings" conveys a feeling of happiness and exuberance which is created not so much by the word but by the letters "e", in all different type faces, floating in the air like soap bubbles or balloons. The letters seem to be joyful and carefree as they float upwards in all kinds of positions without being restricted by lines or margins.

\section{Freiheit - "Freedom Freedom today still exists only in details" gives a rather severe} impression. The big sans ser if "H" seems to form a grid or bars. The "construction" of "H"s also looks like a modern high rise building which covers most of the word "Freiheit." Freiheit is pushed into the corner. This design definitely shows the limitations put on freedom.

Thus the typo-

graphic design,

which is an import-

ant part of all

printed material,

such as books, poetry

and advertising, can

become visual poetry.

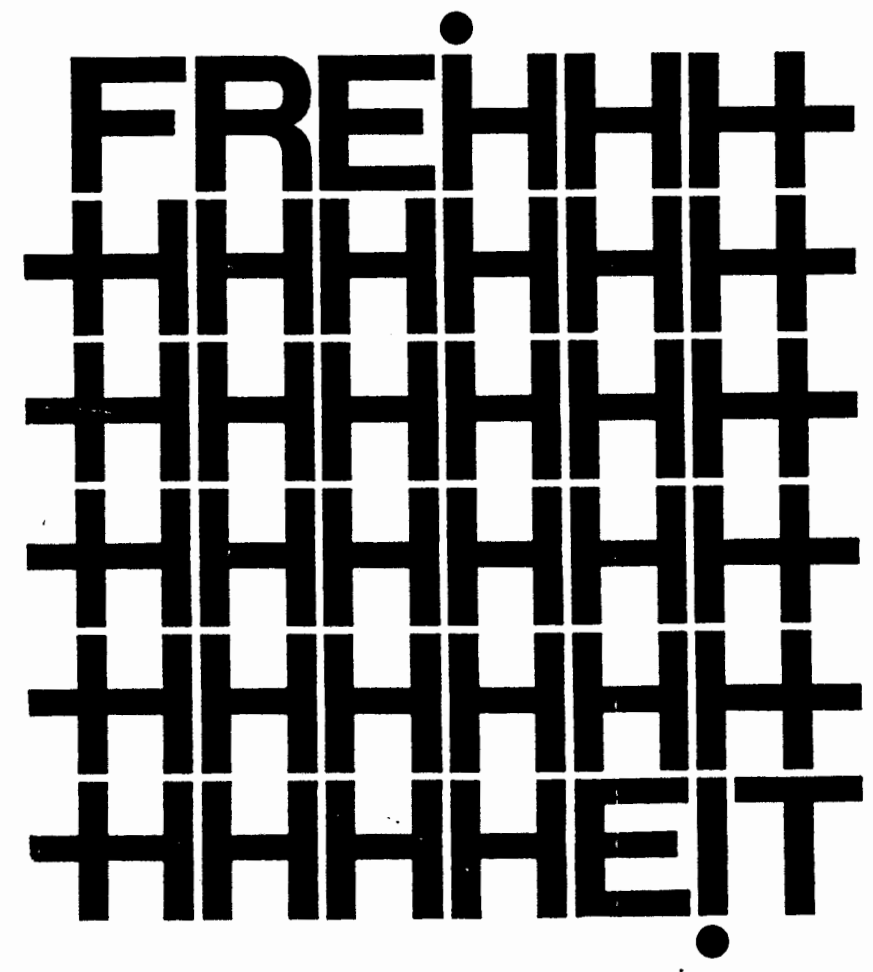


1 Geck, pp. 33, 34.

2 Doir, p. 8.

3 Geck, p. 58.

4 John Lewis, The Anatomy of Printing (London: Faber + Faber Limited, 1970), pp. 34-37.

5 Typography and Design, by United States Government Printing Office Training Ser ies (Washington, D.C.P: GPO, 1951), p. 15.

6 Warren E. Preece, "Typography," Encyclopaedia Britannica: Macropeedia, 1985 ed. XXVI, p. 92.

7 Geck, pp. 60,61.

8 preece, p. 97.

9 Prece, p. 97, Government, p. 18.

10 Dair, pp. $4,5$.

11 James M. Wells, "Type and book design since the 19th century," Encyclopeedia Britannica:

Mecropoedia, 1985 ed. XXVI pp. 97-99.

12 Dair, p. 46.

13 Dair, p. 130.

14 Donald M. Ander son, The Art of Written Forms: The Theory and Practice of Calligraphy (New York, Chicage: Holt, Rinehart and Winston, Inc., 1969), p. 143.

15 Dieter Urban, "Communications Design Education," Novum Gebrauchsgraphik, Nov. 1982, p. 7.

16 Locher and Broos, n.p.

17 Ruari McLean, Jen Tschichold: Typographer (Boston: Dovid R. Oodine, 1975), pp. $29,30$. 18 Wells, p. 102. 
19 Locher and Broos, n.p.

20 Anderson, pp. 190, 191.

21 Locher and Broos, n.p.

22 Dair, p. 145

23 McLean, p. 29.

24 Dieter Urban, "Communications Design Education," p. 7.

25 Dieter Urban, "Typography: Luxury or Necessity?" Novum Gebrauchsaraphik, June, 1984, p. 8.

26 Stephan Seilern und Aspang, "Schule für Gestaltung St. Gallen," Novum Gebrauchsaraphik, Oct. 1982, pp. 42-47. 


\section{CHAPTER VI}

\section{CONCRETE POETRY AND ADVERTISINO}

"das neue gedicht... es ist memor ierbar und als bild einprägsam" writes Gomringer. 1 The two attributes here ascribed to a concrete poem seem to suit the intent of advertising perfectly, because an advertisement is most effective and successful when both its picture (shape, illustration) and content are easily remembered.

There are many statements about concrete poetry which link it to advertising. Some poets refer to concrete poems as "useful objects", others point out similarities in the execution of concrete poems and advertising. One of the definitions of concrete poetry given in the Noigandres' "Pilot Plan" is: "The poem-product: useful object." 2 Gomringer also defines a concrete poem as a "seh- und gebrauchsgegenstand: denkgegenstand-denkspiel."3 Döhl writes about Gomringer's statement: "Der Gebrauchstext, den er im Auge hat, dürfte wohl eher der Werbetext sein...."4 Indeed, Gomringer has always been interested in advertising. "die konkrete poesie interessiert sich für sprachliche probleme jeder art, also zum beispiel auch für die sprache in der werbung ...." wrote Gomringer in a letter to industrialists. 5 In a discussion with Ekkehard Juergens, Gomringer stated that he worked more for advertising than for poetry books. 6

Even though concrete poetry failed to create a "Gemeinschaftssprache," as was Gomringer's hope, Auwera is of the opinion that concrete poetry was in a certain way successful, namely, "in einem anderen für die Gesellschaft relevanten Sektor: dem der Werbung." He continues: "Die Gleichzeitigkeit verbaler und nicht verbaler Mitteilung hat Konkrete Poesie mit guten Werbeanzeigen und Plakaten gemein." 7 Max Bense mentioned the same idea in his essay 
"Concrete Poetry." He wrote: "Concrete texts are often closely related to poster texts due to their reliance upon typography and visual effect; that is, their aesthetic communication scheme often corresponds to that of advertisements. "8

The following advertisements, which closely resemble concrete poems, represent only a small sampling. The examples were chosen to show that the wide range of possibilities matches that of concrete poetry, and also to show that not all advertisements are equally successful.

The first example is an advertising/constellation by Oomringer.

$$
\begin{gathered}
\text { für Büros mit grosser Tatkraft } \\
\text { plant und gestaltet } \\
\text { Witzig } \\
\text { im Hochhaus zur Palme } \\
\text { Zürich } \\
\text { plant und gestaltet } \\
\text { für Büros mit grosser Ordnung } \\
\text { plant und gestaltet } \\
\text { Witzig } \\
\text { im Hochhaus zur Palme } \\
\text { Zürich } \\
\text { plant und gestaltet } \\
\text { für Büros mit grossem Erfolg } \\
\text { plant und gestaltet }
\end{gathered}
$$

The constellation continues in the same manner

$\begin{array}{cc} & \text { "mit grossem Flair } \\ & \text { mit grossen Chefs } \\ & \text { mit grosser Arbeit" } \\ \text { "mit grosser Leistung." } & \end{array}$

The advertising poem could be divided after every line "für büros" without losing its meaning. Consequently the poem has greater versatility because, according to Gomringer, it can be used in many different ways, in shorter or longer version, over a longer period of time. Gomringer also points out that this type of advertising text resembles his constellations. ${ }^{10}$ However, on the semantic level it does not create new relationships between words. The same lines are merely repeated in the same order. The meaning of those lines is applied to only one new word in every six lines. 
In its symmetry Gomr inger's advertisement is similar to many poems by Arno Holz. The last stanza of Holz' poem "Kurfürstendammvilla" can serve as a comparison.

\author{
Ich \\ küsse entzückt der Hausfrau die Hand, \\ enttäusche \\ einen älteren, ernsten, \\ wohlproportionierten, würdevollen, glattrasierten \\ Herrn \\ in \\ galoniertem Blaufrack \\ baumwollenen Handschuhen und weißseidenen \\ Wadenstrümpfen \\ durch \\ eine Mark Trinkgeld \\ und \\ verschwinde. 11
}

In his book Was ist kas Konkrete an einem Gedicht? Heißenbüttel writes about Holz' poem: "... An die Stelle der metaphor ischen Bezüge ist hier der vokabuläre Katalog getreten ..., der Katalog wird zum Gedicht dadurch, daß er das Konkrete der Wörter in ihrem Funktionswert nebeneinander stellt ...." 12 Holz' stanza can also be reduced without losing much meaning by terminating it after "Hand," "Herrn," "Blaufrack" etc. Here the new material which is added expands the meaning of the poem. The advertising poem consists of a "vokabuläre Katalog" of very narrow scope. The repeated use of the name and location of the firm takes precedence over any other word associations. Thus even though the constellation "form" is used, as concrete poetry Gomr inger's advertisement is not very successful.

The typogram is a form of concrete poetry which emphasizes the shape of the letters. It is often aesthetic typography. In advertising, according to Roderich Feldes, the typogram mainly consists of logograms or trademarks. Feldes uses the typogram/trademark of the steelworks of Südwestfalen as an example. The typogram resembles a corner and two sides of a building. The name of the company provides the letters used to construct the typogram. Different sizes of letters are used only to form functional building blocks for the image of the building "Südwestfalen." Therefore the typogram can only function as an advertisement and can not be separated from it. 


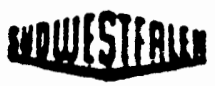

13

The tautology is the weakest form of concrete poetry because form merely repeats content. Yet the efficiency of this "double message" is important for advertising. The "Volltreffer" tautology was used by a real estate firm.

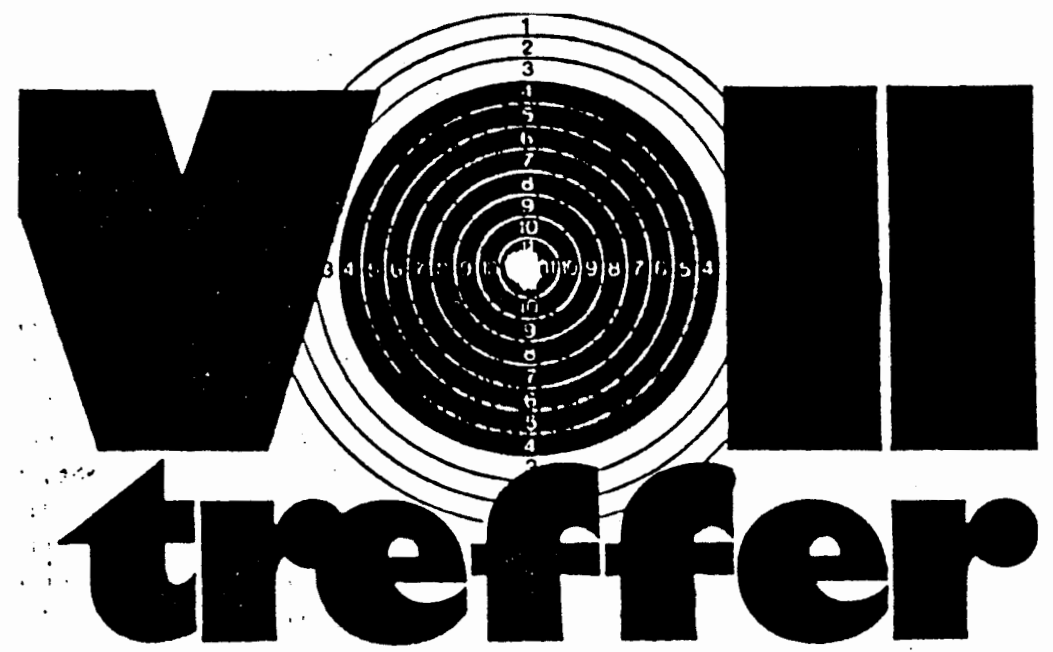

EigentumsWohnungen,Offenbach/Mainpark

The firm referred to the buying of one of its "Eigentumswohnungen" as a "direct hit" ("Volltreffer"). 14 The "Volltreffer" is shown graphically as the picture of a dart board. It is also printed in thick black letters with the round shape of the dart board taking the place of the 0 . In the advertising tautology the visual design stands out. The name and address of the firm are printed in smaller letters. The "Volltreffer" tautology gains its strength as concrete poetry from the fact that it is a tautology which can function independently from the advertisement.

According to Gomringer, ideograms are "einprägsame seh-gegenstände von logischem aufbau." 15 The ideogram tries to convey meaning through the arrangement of letters or words. The ideogram/advertisement for the city of Stuttgart looks as if it has been gradually developed in five stages, thus showing the action of the word "Entwicklung." 16 Here again the visualization is separate from the explanation. Feldes claims the dual use of visual poetry and information is similar to the method used by some concrete poets. ${ }^{17}$ Two examples of the use of visual poetry and 
information are: Kriwet's "Rundscheibe" for which there exists a booklet with a complete explanation, and Bremer's "Anlaesse" which contains information about many of his ooems.

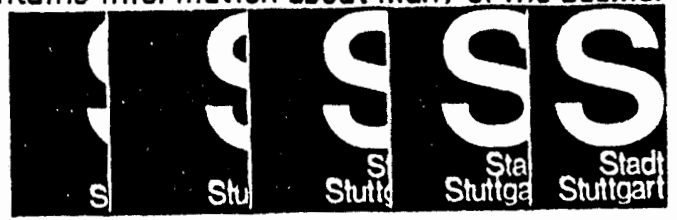

$$
\begin{aligned}
& \text { Interessant: Systementwicklung } \\
& \text { Im Lienste der } \\
& \text { Stadt- und Verkehrsp anung } \\
& \text { Stuttgart }
\end{aligned}
$$

Another important ideogram/advertising is "Break-Up Cough" designed for a phar maceutical company by Herb Lubalin and included in Richard Kostelanetz' book Imaged Words \& Worded Images. The action of the text is created by the same method used to make collages, namely, by tearing up the letters of the word "cough." In a collage, however, the torn pieces are usually taken from different sources and are over lapping each other.

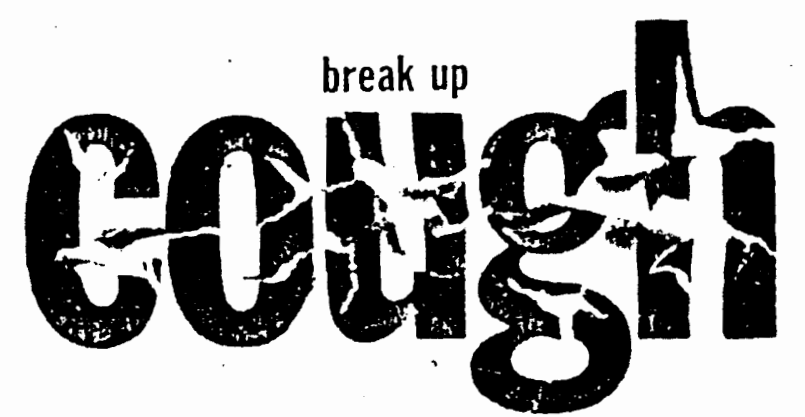

Mon's quote about collages not only applies to the many collages made by him but also to

the advertising collage created by Sirje Helder. Mon writes:

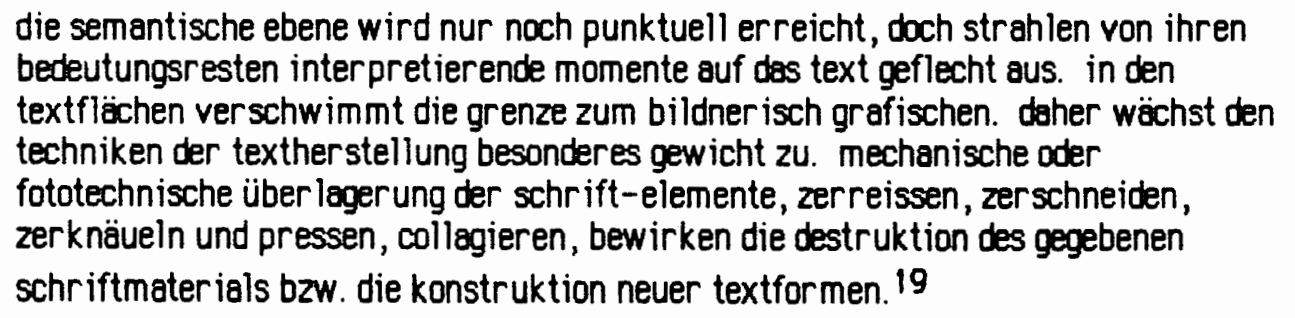

Helder used "found" images, cut from newspapers and magazines, for her collage and arranged them in such a way that they formed a "storm of letters." The letters seem to keep coming down. In smaller letters under the collage was the question "Caught in the communication blizzard?" 20 
Helder's collage can function as a concrete poem independently from the advertisement. Her collage/advertisement helps to explain the fact that an odvertisement can contain concrete poetry.

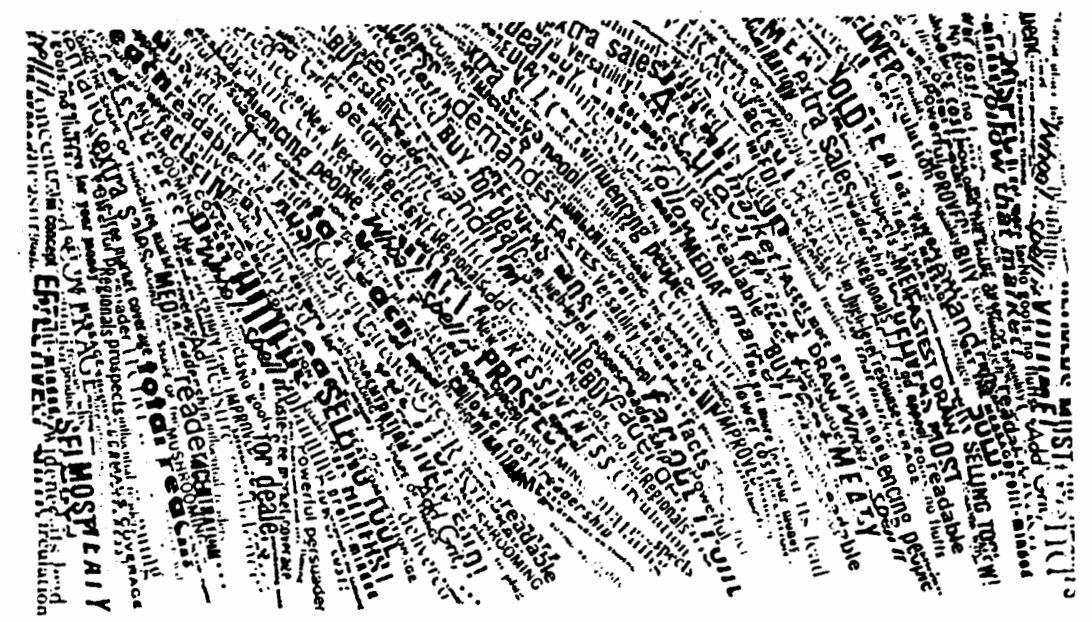

The last example shown here is similar to Kriwet's "Rundscheibe." The advertisement consists of circles made up of words. The circles are not closed and the open area in each consecutive circle is moved to the left thus creating an impression of circular movement. The words "Word Ways" are repeated six times to form a circle. The size of the letters changes from small in the center to large at the outside. The reader might well think that the "Word Ways" could get bigger and continue indefinitely. Thus the advertisement/poem for the magazine "Recreational Linguistics" shows what has been created with recreational linguistics. At the same time it implies the unlimited possibilities of recreational linguistics. ${ }^{21}$ (see next page)

"Word Ways" is a concrete poem/adver tisement where the poem is the advertisement. The poem is not weakened by the advertising as is the case in Oomringer's constellation/advertisement. In "Word Ways" the advertisement is a concrete poem and not a mere shape as in the typogram/trademark. Thus advertisement and concrete poem complete each other to form a concrete poetry advertisement. Now the question must be asked: "Can advertising be considered as concrete poetry, visual poetry?" 
PI

W68

19

2 a 8 ?

$\because 30$

$\lim _{1}$

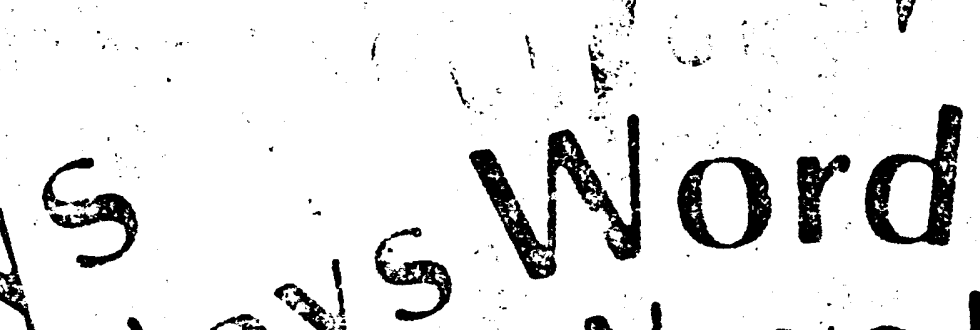

\section{Nays \\ M}

$1 /$

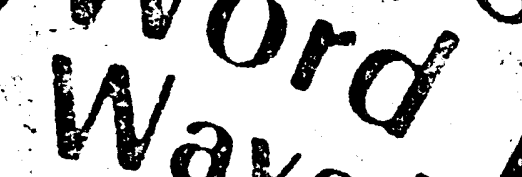

Nord Wars W 8)

$0^{0} J^{2}$ ways

$n_{0,0}$ rodis

co 2o do word Ways

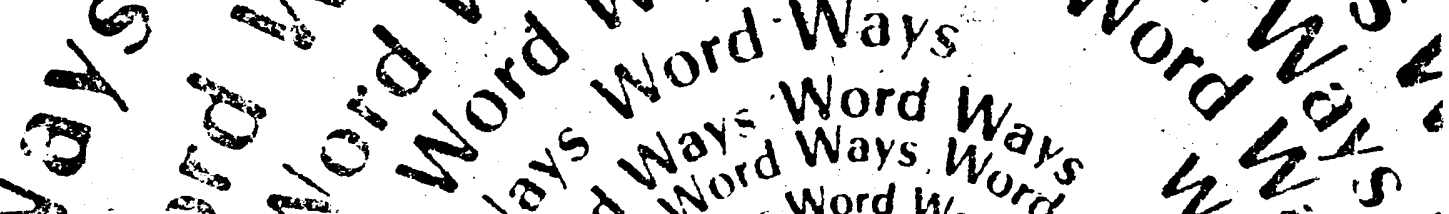

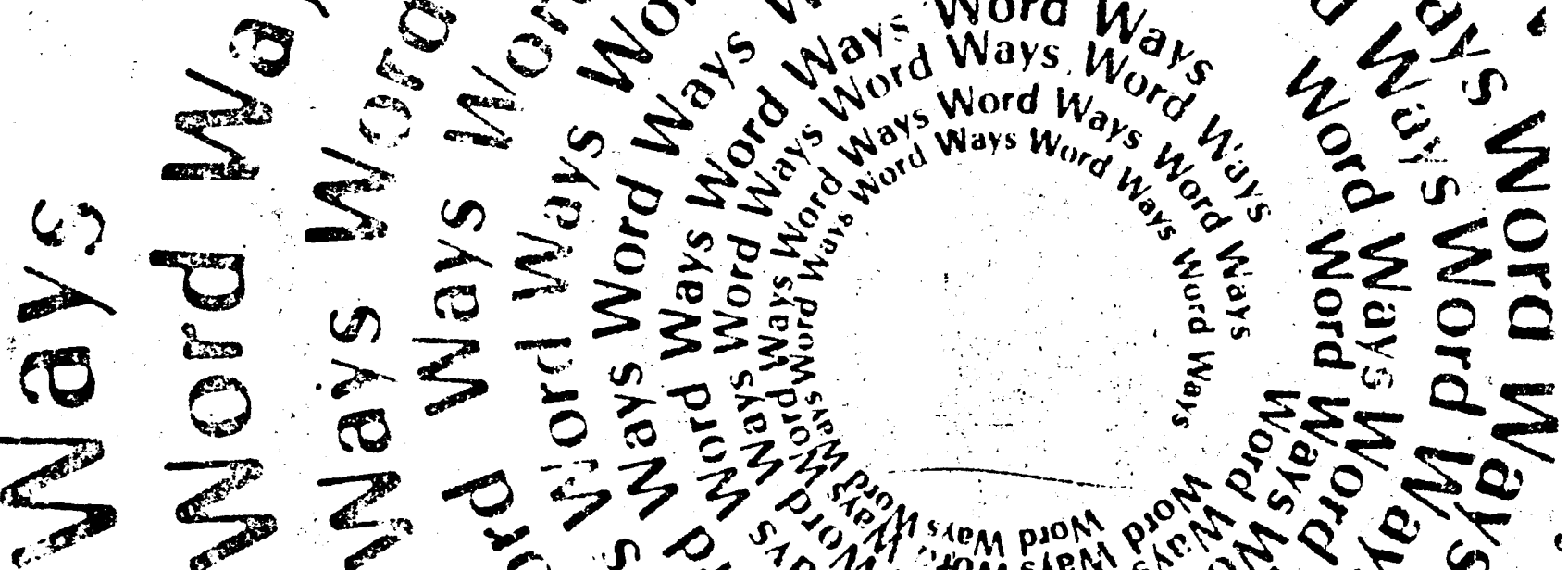

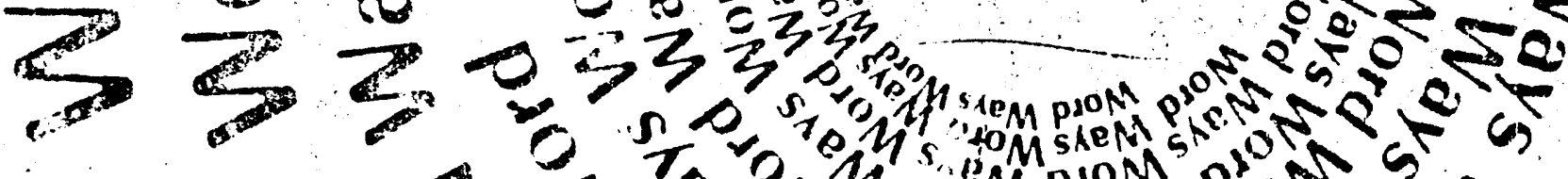

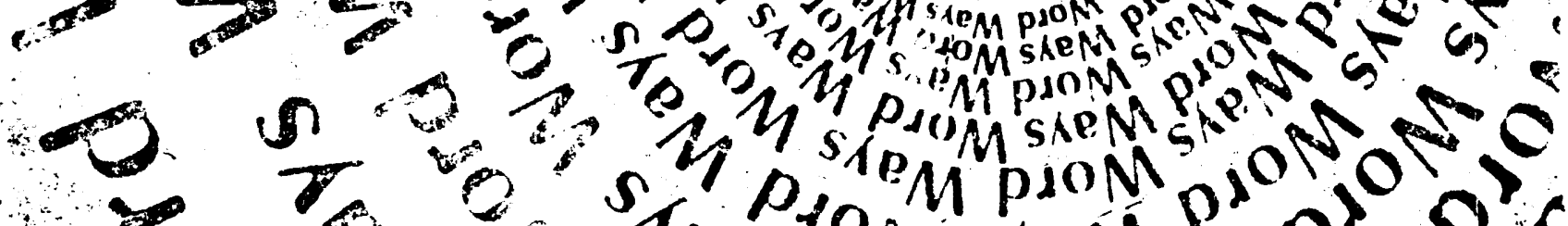
$50 \%$ Tom shen

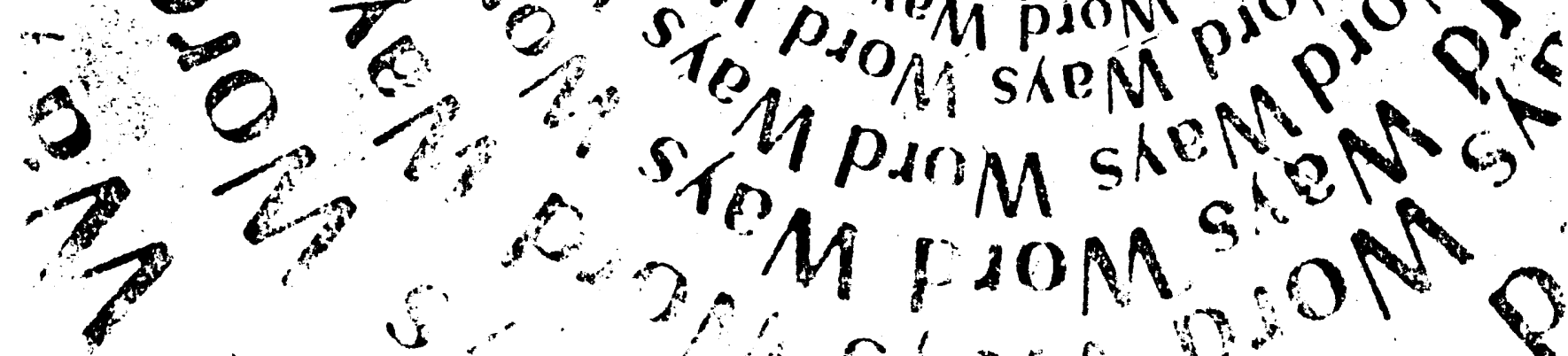


The statements by the Noigandres group and Gomringer that a concrete poem is a functional object could be interpreted as an affirmation that indeed advertisements can be poetry. Auwera makes the stipulation "good" advertisements without specifying what constitutes "good" advertisements.

In order to know whether advertisements are concrete poetry/visual poetry we first have to know what earerete poetry is. Solt wr ites: "When we know for sure what language ts, we will know for sure whether these texts (concrete poems) are poetry.22 The same applies to "good" advertising. There is no set definition because as soon as concrete poetry/visual poetry is defined, it is at the same time confined within this definition and loses the capacity for innovation and experimentation, two elements crucial to the development of concrete poetry.

Gomringer hopes that eventually the distinction between "gebrauchsliteratur" and "designierte dichtung" will disappear and "daß es in zukunft überhaupt noch eine art wirklicher gebrauchsliteratur geben wird." 23 Works by Dencker and Kostelanetz show the realization of Gomringer's idea. Feldes notes that Dencker in his Visual Poesie international discusses, on an equal basis, examples from both visual poetry and advertising. 24

Richar Kostelanetz produced the book Imaged Words \& Worded Images. He writes it is "an excursion into an intriguing new kind of art, derived as much from contemporary advertising as from the experiments of occasional poets and writers throughout the centuries." 25 Kostelanetz' book contains a selection of visual poems by different authors, among them autonomous typography by Klaus Burkhart, work by F. Kriwet and the advertsing design "Break-Up Cough" by F. Lubalin. As his only classification Kostelanetz distinguishes between "imaged words" ( "lenguage is enhanced through pcitorial means") and "worded images" ( "pictures made with words and letters"). The works are unsigned, and credits--name and profession, poet/designer/artist--are given in the back of the book. It gives the reader, per user the chance to approach the work with an open mind, without the prejudice of labels. Kostelanetz writes that typographical innovations "in the best 
word-imagery are both profound perceptual experiences and unprecedented forms of artcommunication ... within one inclusive form, of both poetry and painting. "26

In Dencker's and in Kostelanetz" books, then, advertisements are included under the collective name visual poetry (concrete poetry). There is no need to decide what, in general, constitutes "good" advertising or the best word imagery. Each advertisement/visual poem will have to be judged for its own merits. Thus Solt's quate about a visual poem can be applied to some advertisements also.

The visual poem as a functional design can humanize the materials and techniques of the mass media of communication, can make them available to the human spirit. The poem comes alive once again in the world it has been assumed would destroy it. 27 


\section{NOTES}

1 Gomringer, "vom vers zur konstellation," p. 156.

2 Augusto de Campos, Pignatari, Haroldo de Campos, "Pilot Plan for Concrete Poetry," p. 72.

3 Gomringer, "vom vers zur konstellation," p. 156.

4 Döhl, p. 291.

5 Auwera, p. 37.

6 Ekkehard Juergens, "Wie kankret kann Konkrete Poesie sich engagieren? Ein Gespräch mit Eugen Gomringer, geführt von Ekkehard Juergens," Iext + Kritik, No. 30(1971), p. 45.

7 Auwera, p. 37.

8 Max Bense, "Concrete Poetry, " trans. Irène Montjoye Sinor and M.E.S., (from "Rot") in Concrete Poetry: A World View, ed. Mary Ellen Solt (Indiana Univ. Press, 1968), p. 73.

9 Feldes, p. 84.

10 Feldes, p. 84.

11 Helmut Heißenbüttel, Was ist das Konkrete an einem Gedicht? (Itzenhœe-Münsterdorf: Ver lag Hansen \& Hansen, 1969), pp. 97, 98.

12 Heißenbüttel, pp. $97,98$.

13 Feldes, pp. $80,81$.

14 Feldes, pp. 77-79.

15 Qomringer, "definitionen zur visuellen poesie," p. 163.

16 Feldes, p. 91.

17 Feldes, p. 76.

18 Anderson, p. 236.

19 Franz Mon, "collage decollage," in Text Buchstabe Bild introd. Felix Andreas Baumann (Zürich: Zürcher Kunstgesellschaft, n.d.), p. 11. 
20 Anderson, p. 231.

21 Journal of Recreationai Linquistics, Vol. XXVII, No. 3, 1984, front page.

22 solt, p. 64.

23 Gomringer, "vom vers zur konstellation," p. 156.

24 Feldes, pp. 73, 74.

25 Kostelanetz, back cover.

26 Kostelanetz, n.p.

27 Solt, p. 61. 


\title{
CHAPTER VII
}

\author{
SUMMARY
}

Concrete poetry, with its strong emphasis on innovation and experimentation, is sometimes referred to as a completely new poetry. However, there were other times in the history of literature when poets deviated from the strictly linear form of the poem, and instead made poems in the shape of objects.

The history of such picture poems can be traced back as far as 300 B.C.. There are three main per iods when production of picture poems was at a high point. During the Alexandr ine period poems were written in the shapes of a shepherd's pipe or an altar. The poets of the Carolingian Renaissance added gr id poems to the already existing shapes. The Baroque period was the time of the proliferation of "occasion poems" ("Gelegenheitsgedichte"), poems whose forms fit the occasions for which they were made.

The early picture poems resemble concrete poems, yet they can not be considered concrete poetry, because content does not relate closely to shape. In the tautology, the weakest form of concrete poetry, shape repeats content. In the ideogram, the classic form, there is no definite outline or shape but instead there exists a delicate balance between spatial arrangement and content.

In 1955 Oomringer and Pignatari chose the name "concrete poetry" for their experimental poetry. Since that time the meaning of concrete poetry hes changed significantly. The concrete poetry of the early years of its development is often termed "classic concrete poetry." Döhl calls it a "literary trend" ("literarische Tendenz") and an "intermittant stage" 
("Durchgangsstadium") for the poets who went beyond concrete poetry in its narrower meaning.' Concrete poetry today is the collective name for many new kinds of poetry.

Some of the newer forms of concrete poetry warrant further independent study. There are both, the fascinating new field of computer generated poetry and the "Hörspiel," which according to Mon, plays a very important roll in experimental poetry in Germany today. Furthermore there is the conceptual concrete poetry which Schmidt calls "post-concrete poetry" and which he describes as: "... attempts at generating more complex texts (than those of concrete poetry) through elaborate integration of optical and linguistic-notional constituents." 2

The concrete poetry referred to in this thesis is the concrete poetry of the early years, the fifties and sixties. It is the poetry which was the product of two independent parallel movements in Germany and Brazil and was named concrete poetry by the innovators Gomr inger and Pignatar $i$ at a meeting in Germany. The meeting sparked an international movement. Its beginning, in the mid-fifties, was a time when artists from many different backgrounds came together to create a new experimental poetry, a combination of visual arts, literature and design. Concrete poets formed groups in Stuttgart, Darmstadt and Vienna. The groups disbanded after a few years and the artists went their separate ways. The complexity of concrete poetry can, in part, be explained by the varied backgrounds of the poets. Even in its beginning stage there were already too many different kinds of poetry to fit an easy definition.

The poets set forth their ideas in manifestoes, each stressing different aspects of concrete poetry. Yet the manifestoes contain some basic elements which apply to concrete poetry in general. One such element is the new typographical arrangment, first introduced by Mallarmé, in which the page surface becomes part of the poem. The reading direction can be from left to right, right to left, up, or down. Many of the typographic innovations were made pssible by the technological improvements of the printing process. Another common feature is the use of mainly lower case sans ser if letters, a factor which can be traced to the influence of the Bauhaus School.

The Bauhaus stressed functional typography devoid of decorations. Typagraphy remains functional as long as it is readable. If the typography in concrete poetry is pursued to the limit, to 
where the individual letters are no longer recognizable, it can cross over into the field of graphic arts and become autonomous typography. The functionalism of the Bauhaus not only applies to the typography but also to the use of language. The concrete poets use a reduced basic language often consisting of single words or parts of words.

Constructivism and the ideas of the concrete painters are represented in the concrete poems. The concrete poets use the word, or parts of a word, as basic material to construct their poems, the same way the concrete painter used basic colors and shapes to construct a painting. The aim of a concrete poem is not the conveyance of a message or an idea. The poem stands for itself, for the reader, peruser to exper iment with or to finish according to his liking.

If the concrete poets made use of modern typography and design, so did advertising. Both use aesthetic communication, and therefore it is not irrelevant that certain advertisements resemble concrete poetry. Some of today's advertisements carry on the tradition of concrete poetry, and in effect can be considered concrete poetry despite the fact that they are used for advertising.

A concrete poem is a combination of visual art, literature and design. Such a new poem requires a new kind of reader, one who sets aside conventional expectations. Schmidt explains why different groups of people do not appreciate concrete poetry: "Die Gebildeten finden dann in der Kondreten Dichtung zu wenig Tiefsinn, die 'Linken' zu wenig gesellschaftliches Engagement, die Konsumenten zu wenig Stoff ...."3 Concrete poetry is an experimental poetry and strongly visual. It can not be judged according to the guidelines set for conventional poetry. Concrete poetry needs a reader who does not judge it for its shortcomings, but is willing to experiment and become a participant. Gomringer stresses the "spiel" aspect of his poetry; Bense calls it fascination. Garnier's definition of concrete poetry (in its broader meaning) stated in the "Position I of the International Movement," emphasizes joy, and fits best in our ever changing society.

Joy in the absence of narrow certainties, joy in the world open as it is, joy of creation in creation infinitely spacious, these kinds of poetry are not 'fixed,' they are constantly becoming. ${ }^{4}$ 


\section{NOTES}

1 Reinhard Döhl, Letter to author ( 10 October, 1984).

2 Siegfried J. Schmidt, "

Perspectives on the Development of Post-Concrete Poetry," in Poetics Today: theory \& analysis of literature \& communication, Vol. III, No. 3, 1982, p. 120.

3 Siegfried J. Schmidt, "Zur Einführung: Dichtung als Sprache --Sprache als Dichtung," in Konkrete Dichtung: Texte und Theor ien (München: Bayer ischer Schulbuch-Verlag, 1972), p. 10.

4 Garnier, p. 80. 
BIBLIOBRAPHY

Anderson, Donald M. The Art of Written Forms: The Theory and Practice of Calligraphy. New York, Chicago: Holt, Rinehart and Winston, Inc., 1969.

Auwera, Berold van der. "Theor ie und Praxis Konkreter Poesie." Text + Kritik, No. 30 (1971), pp. $33-41$.

Bann, Stephan, ed. Concrete Poetry: An International Antholocy. London: London Magazine Editions, 1967.

"Bauhaus." New Encyclopaedia Britannica: Micropaedia. 1985 ed.

Beyer, Renate. "Innovation oder traditioneller Rekurs?" Text + Kritik, №. 30 (1971), pp. 2332.

Bory, Jean-Francois. Once Again. Trans. Lee Hildreth. New York: New Directions Publishing Corp., 1968.

"Constructivism." Encyclopaedia Britannica: Micropaedia. 1985 ed.

Dair, Carl. Design with Type. Toronto: University of Toronto Press, 1967.

Dischner, Gisela. "Konkrete Kunst und Gesellschaft." In Über die Univerständlichkeit: Aufsätze zur neuen Dichtung. Hildesheim: Gerstenberg Verlag, 1982, pp. 85-91.

Döhl, Reinhard. "Konkrete Literatur." In Sonderdruck aus Deutsche Begenwartsliteratur: Ausgangspositionen und aktuelle Entwicklungen. Ed. Manfred Durzak. Stuttgart: Reclam, n.d.

Draper, R.P. "Concrete Poetry." New Literary History, V.2, n.2, 1971, pp. 329-340.

Eisenstein, Elizabeth L. The Printine Press as an Acent of Chanoe. Cambridge: Cambridge Univ. Press, 1979. 
Emmerich, Wolfgang. Kleine Literaturaeschichte der DDR. Darmstatt: Herman Luchterhand Verlag, 1981.

Feldes, Roder ich. Das Wort als Werkzeug. Oöttingen: Otto Schwarz \& Co., 1976.

Franke, Herbert W. Computer Graphics, Computer Art. Trans. Oustav Metzger. New York: Phaidon Publishers, 1971.

Oeck, Elisabeth. Johannes Qutenberg. Bad Godesberg: Inter Nationes, 1968.

Gomringer, Eugen, ed. konkrete poesie: deutschsprachige autoren. Stuttgart: Reclam, 1972.

Gomringer, Eugen. "Some remarks on the Notion 'Visual Poetry'." West Coast Poetry Review, Vol. Y, No. 3 (1979), pp. 153-154.

Gumpel, Liselotte. "Concrete" Poetry from East and West Germany: The Lanquage of Examplarism and Experimentalism. New Haven: Yale, 1976.

Hage, Volker. "Rückblick auf die Konkrete Poesie: Ernst Jandl und Oerhard Rühm." In Die Wiederkehr des Erzählers. Frankfurt a M., Berlin, Wien: Ullstein, 1982, pp. 32-52.

Handt, Friedrich, ed. Deutsch-Gefrorene Sprache in einem gefrorenen Land? Polemik. Analyse, Aufsätze. Berlin: Heenemann, 1964.

Hartung, Harald. Experimentelle Literatur und konkrete Poesie. Oöttingen: Vandenhoeck \& Ruprecht, 1975.

Hedrick, Hannah L. Theo Van Doesburg: Progandist and Practioner of the Avant-Garde, 19091923. Ann Arbor, MI: UMI Research Press, 1973, 1980.

Heißenbüttel, Helmut. Was ist das Konkrete an einem Gedicht? Itzehoe-Münsterdorf: Hansen und Hansen, 1969.

-.---.- Zur Tradition der Moderne Aufsätze und Anmerkungen 1964-1971. Berlin: Hermann Luchterhand, 1972.

Higgins, Dick. Oeorge Herbert's Pattern Poems: In Their Tradition. West Glover: Unpublished Editions, 1977.

Jones, W.T. The Sciences and The Humanities: Conflict and Reconciliation. Berkeley: Univ. of California Press, 1965. 
Journal of Recreational Linquistics. Yol. XVII, No. 3, 1984.

Juergens, Ekkehardt. "Wie konkret kann Konkrete Poesie sich engagieren? Ein Gespröch mit Eugen

Oomringer, geführt von Ekkegardt Juergens." Iext + Kritik, No. 30 (1971), pp. 43-47.

Kafelanos, Emma. "Purification of Language in Mallarmé, Dada and Visual Poetry." West Coast

Poetry Review, Vol. Y, No. 3 (1979), pp. 51-59.

Kessler, Dieter. Untersuchungen zur Konkreten Dichtung. Meisenheim am Glan: Anton Hain, 1976.

Kopfermann, Thomas. Fundamentalpoetik und Textpraxis einer Neo-Avantarde. Frankfurt am

Main, Bern: Peter D. Lang, 1981.

Kostelanetz, Richard, ed. Imaged Words \& Worded Images. New York: Outerbridge \& Dienstfrey, 1970.

Lechène, Robert. "Printing." Encyclopaedia Britannica: Macropaedia. 1985 ed.

Lewis, John. Anatomy of Printing. London: Faber + Faber Limited, 1970.

Liede, Alfred. Dichtung als Spiel: Studien zur Unsinnspoesie an den Grenzen der Sprache. Berlin:

Walter de Oruyter \& Co., 1963. 2 vols.

Locher. Hans, and Kees Broos, eds. Edition Hansiörg Mayer. Den Haag: Haags Oemeentemuseum, 1968.

McLean, Ruari. Jan Tschichold: Typographer. Boston: David R. Oodine, 1975.

McLuhan, Marshall. Understanding Media. New York: McOraw Hill, 1964.

..... The Gutenberg Galaxy: The Making of Typographic Man. Toronto: Univ. of Toronto Press, 1962.

Mon, Franz. hören ohne aufzuhören. Linz: Heimrad Bäcker, 1982.

Ong, Walter J., S.J. The Presence of the Word. New Haven and London: Yale Univ. Press, 1967.

Preece, Warren E. "Typography." Encyclopaedia Britannica: Macropaedia. 1985 ed.

Reichert, Klaus, ed. The Best of H.C. Artmann: Lyrik, Theater, Prosa. Theoritisches. 3rd ed. Frankfurt am Main: Suhrkamp, 1970.

Rook, O.J. de, ed. anthologie visuele poëzie. Den Haag: Bert Bakker, 1975.

Rüegg Ruedi, Oodi Fröhlich. Typographische Grundlagen. Zürich: ABC Edition, 1972. 
Schmidt, Dr. Siegfried J., ed. Konkrete Dichtung: Texte und Theorien. München: Bayerischer Schulbuch-Yerlag, 1972.

-...-. "Perspectives on the Development of Post-Concrete Poetry." In Poetics Todoy: theory \& analysis of literature \& communication. Vol. III, No. 3, 1982.

-..---1emente einer Textpoetik: Theorie und Anwendung. München: Bayerischer Schulbuch-Verlag, n.d.

-...-. . "Das Kontinuum Projekt." In Kunstforum International. Band 37.

Seilern und Aspang, Stephan. "Schule für Bestaltung St. Gallen." Novum Gebrauchsaraphik, Oct. 1982, pp. 42-47.

Slagter, Erik, ed. Visuele Poëzie: Een bloemlezing konkrete en visuele gedichten. Brussel: Manteau, 1977

Solt, Mary Ellen, ed. Concrete Poetry: A World View. Indiana Univ. Press, 1968.

Steinbach, Dietrich, ed. Experimentelle und Konkrete Poesie: Vom Barock zur Gegenwart. Stuttgart: Ernst Klett, 1981.

Steiner, Wendy. "Res Poetica: The Problematics of the Concrete Program." New Literary History, Vol. 12,1981 , pp. 529-545.

Stroszeck, Hauke. "Avantgardistische Programmschriften und Spätrezeption: Eine Demonstration am Beispiel von 'konkrete poesie' auf der Schule." Wirkendes Wort, 25, Juli/August 1975 , pp. $215-30$.

Text Buchstabe Bild. Zürich: Zürcher Kunstgesellschaft, n.d.

Typography and Design. by United States Oovernment Printing Office Training Series. Washington, D.C.: $\mathrm{GPO}, 1951$.

Urban, Dieter. "Typography: Luxury or Necessity?" Novum Gebrauchsgraphik. June, 1984, pp. 4-11.

. "Communications Design Education." Novum Qebrauchsgraphik, Nov. 1982, pp. 69. 
Wagenknecht, Christian. "Proteus und Permutation: Spieiarten einer poetischen Spielart." Text + Kritik, No. 30(1971), pp. 1-10.

Wells, James M. "Type and book design since the 19th century." Encyclopaedia Britannica: Macropaedia. 1985 ed.

Wildman, Eugen, ed. Anthology of Concretism. Chicago: Swallow Press, Inc., 1969.

Williams, Emmett, ed. An Anthology of Concrete Poetry. New York: Something Else Press, Inc., 1967.

Wisbey, R.A., ed. The Computer in Literary and Linquistic Research. Papers from a Cambridge Symposium. New York: Cambridge Univ. Press, 1971.

Wulff, Michæel. Konkrete Poesie und Sprachimmanente Lüge: Von Ernst Jandl zu Ansätzen einer Sprachästhetik. Stuttgart: Akadem ischer Verlag Hans-Dieter Heinz, 1978. 